\title{
المسئولية عن الذكاء الاصطناعي \\ بين القانون الخاص والقانون العام
}

\author{
بجاث مفرم الى مؤهر \\ الجوانب القانونيت والاقتصاديتّللذكاء الاصطناعي \\ وتكنولوجيا المعلومات

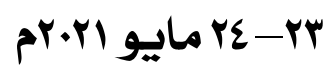 \\ كليتا الحقوق- جامعت المنصورة مايو
}

shel

أ.د/ محمد محمد عبد اللطيف

أستاذ القانون العام

كليت الحقوق -جامعت المنصورة 


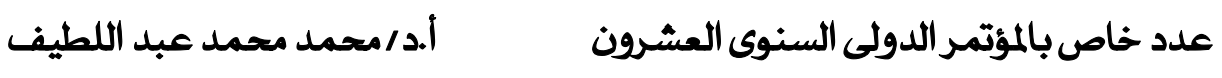

\section{تقديم وتقعيم:}

أصبح الأكاء الاصطناعي مستخدماً على نطاق واسع ومن ملايين البشر يومياً

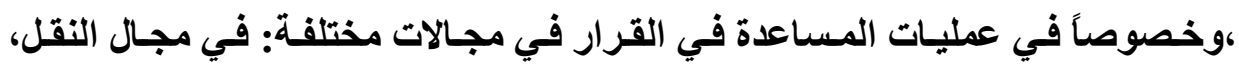
والطب، والمالية، والبيئة، والتنمية المستدامة، والفضاء، والسياسات العامة.. ..إلخ. ويفضل برامج المساعدة في القرار يمكن الوصول إلى حل لـم يـمكن الإنسان من معرفته، أو إيجـاد حلول لمشكلات جديدة لم يكن للإنسان أى خبرة بها، أو اخيراً الحكم على صحة الحل أو تأكيد أو تبرير قرارات.ويعتمد المستخدم غالباً على النتيجة التي انتهى إليها الأكاء الاصطناعي.

ويشير الاعتماد على نظم الذكاء الاصطناعي تساؤلات عديدة ، وتتعلق بكيفية استيعاب القـانون لمعالجة مشكلات المسئولية الناتجـة عن استخدام هذه النظم الذي يمكن ان يسبب أضراراً بـالأفراد. وتثار مشكلة المسئولية في فروع القانون المختلفة ويأتي في مقدمتها القانون المدني وقانون العمل. غير أن هذه المشكلة لم تكن محلًا حتى الآن للار اسة بشكل كافٍ في القانون الإداري. وفي ضوء هذا التقديم رأينا معالجة موضوع البحث وفقاً للخطة الآتية: المبحث الأول: المسئولية عن الأكاء الاصطناعي والقانون المدني المبحث الثاني: المسئولية عن الأكاء الاصطناعي وقانون العمل المبحث الثالث: المسئولية عن الأكاء الاصطناعي والقانون العام 
عدد خاص بالمؤتمر الدولى السنوى العشرون أ.د/محمد محمد عبد اللطيف

\section{المبحث الأول}

المسئولية عن الذكاء الاصطناعي والقانون المدني

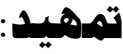

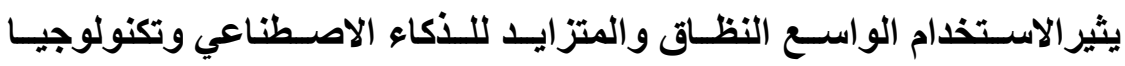

المعلومات التساؤل عن المسئولية الناجمة جراء هذا الاسخدام.ويسأتي في مقدمة التي

تتعلق بهذه المسئولية السؤال الذي يتعلق بمدى كفاية قواعد المسئولية المدنية الحالية

للتعويض عن الأضرار الناجمة جراء استخدام الذكاء الاصطناعي، أو أنها يجب إقرار قواعد جديدة تتعلق بوجه خاص بالأكاء الاصطناعي؟

و إذا كان من السهل القول بوجوب إقرار قواعد جديدة ، إلا أنه يجب أيضاً دائماً

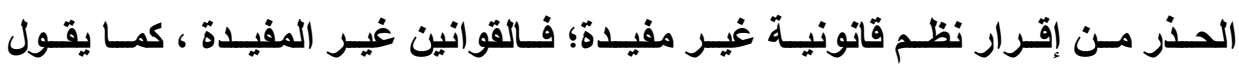

Montesquieu إذا كانت قواعد القانون المدني تبدو كافية وتغني عن تبني أى قواعد جديدة ( (1).

ويبدو أن الاتجـاه السائد حتى الآن هو عدم تـخل المشرع بـإقراررار تشريع

حاص لتنظيم المسئولية عن استخدام الأكاء الاصطناعي. وظهر ذلتك واضحاً في فرنسا

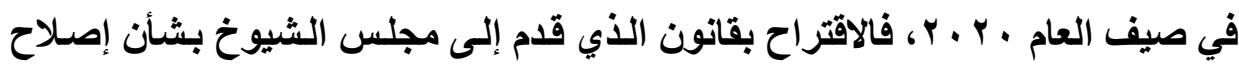
نظام المسئولية لم يتضمن أى إشارة إلى الأكاء الاصطناعي (ץ).

(1) A. Bensamoun et G. Loiseau, L'intelligence artificielle : faut-il légiférer ? D. 2017. 581

(2) Sénat, proposition de loi portant réforme de la responsabilité civile, 29 juill. 2020 


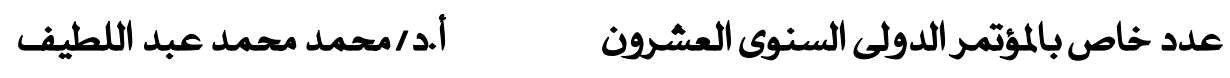

ومع التسليم بتلك الحقيقة إلا أن الذكاء الاصطناعي أحدث تحولاً كبيراً في مجال

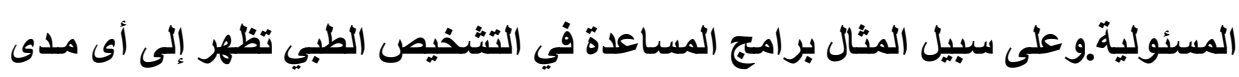

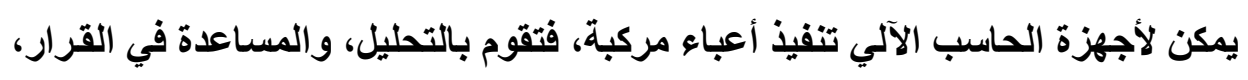

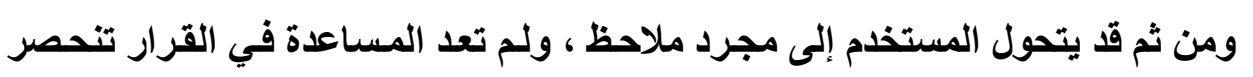
في مساتدة النشاط البشري، ولكن ربما تعديله والحلول محله، ومن ثم تأخذ المسئولية الناتجة عن تلخل الأكاء الاصطناعي بعداً جديداً مختلفاً. تعريف الأكاء الاصطناعي:

لايوجد تعريف واحد أو محدد للذكاء الاصطناعي (1). ويوجد تعريف واسع أو

مفصل للأكاء الاصطناعي بأنه: نظم برمجيات وربمـا أجهزة صممها البشر ذات هدف

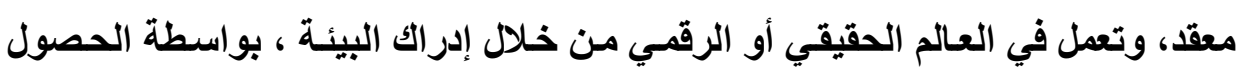

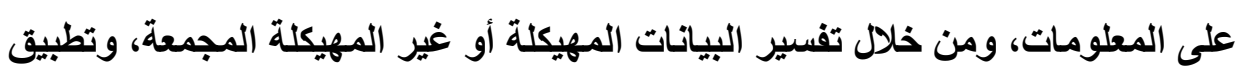
تحليل على المعارف أو معالجة المعلومات المستمدة من تلك البيانـات، وتقرير الإجراء أو الإجراءات الأفضل الواجب اتخاذها من أجل تحقيق هدف معين. ويمكن لنظم الذكاء الاصطناعي إما استخدام قواعد رمزية، أو تعلم نموذج رقمي، كمـا يمكنها أيضاً تكييف الإنف

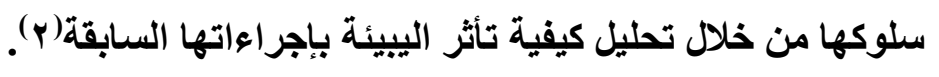

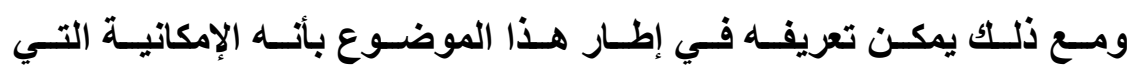

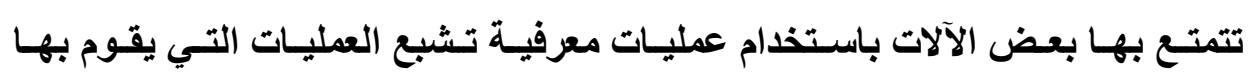
الإنسان.

(1) « Intelligence artificielle » (IA)

(2) Commission européenne, Lignes directrices en matière d'éthique pour une intelligence artificielle digne de confiance ,8avr.2019,§143,p.8. 


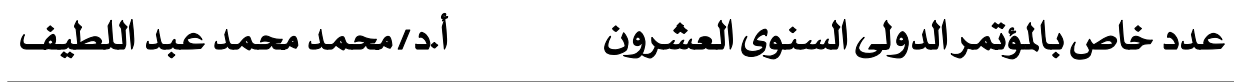

\section{المطاب الأول}

رفض الاعتراف للذكاء الاصطناعي بالمسئولية المدنية

الوضع القانوني للربوت الأكي أو الأكاء الاصطناعي:

تسود في القانون الفرنسي والمصري فكرة أساسية هى التمييز بين الشخص

القانونيLes personnes والأشياء Les choses ـ والأشخاص هم أشخاص هم القياص القانون

objets de droit أما الأشياء فهى أشياء قانونية ون sujets de droit

وتنبغي الإشارة إلى أن الذكاء الاصطناعي هو نظام من نظم البرمجيات. أمسا

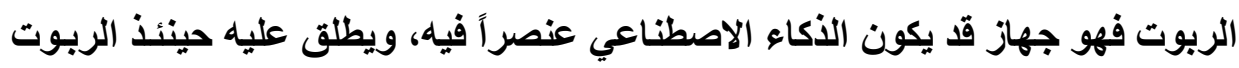

$$
\text { الأكي. وفي الحالتين نكون بصدد ذكاء اصطناعي. }
$$

والسائد أن الريوت الأكي هو شئ قانوني؛ لأنـه من خلق الإنسان، وأنـه نظراً

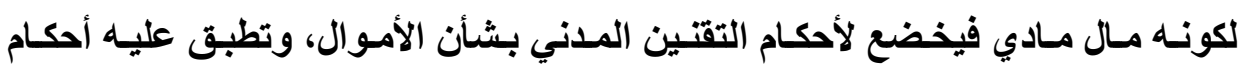

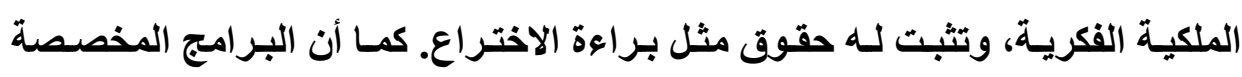
لتشغيل الربوت، وتلك التي يستخدمها الربوت في تنفيذ مهمامه يمكن حمايتها بوصفها

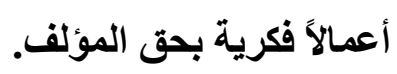

والريوت الأكي مال قابل للتعامل التجاري، وله إسم يتم اختيـاره بعنايـة ، ويتم

تسجيله كعلامة تجارية.

الاعتر اف للأكاء الاصطناعي بالشخصية القانونية:

توجد وجهة نظر ترنو إلى المستقبل مؤداهـا الاعتراف بالشخصية القانونية

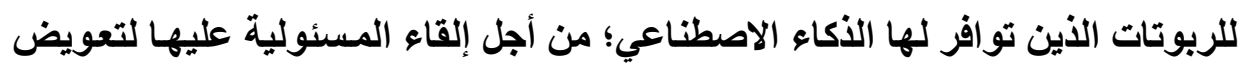

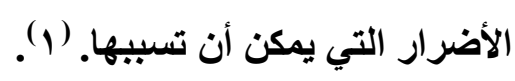

(1) A. Bensoussan, Droit des robots : science-fiction ou anticipation ? D. 


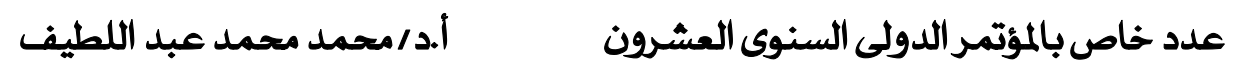

في نظر هؤلاء إن الربوت المستقل الذي يتمتع بالذكاء الاصطناعي هو شخص إليكترونـي مسسئول (1) . وهـا الـرأى يعنـي بوضـوح الاعتراف للربـوت بالشخصية

ودافع عن هذا الرأى أيضاً تقريـر نائب بالرلمـان الأورويـي، كمـا تبنـاه أيضاً

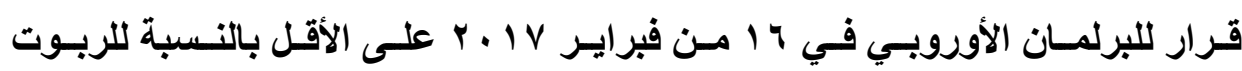
المستقل الأكثر تقدما وهو الذي يأخذ قرارات مستقلة، او يتصرف بطريقة مستقلة مـع

ويوضـح قرار البرلمـان الأوروبـي المشـار إليـه أن إنشاء الثخصية القانونيـة

يهدف إلى جعل الربوت نفسه مسئولاً بحيث يلتزم بتعويض الأضرار الناجمـة للغير، وبدلاً من تقرير مسئولية مصمم الريوت ، أو الصانع، أو المالك ، أو المستخلم لله عن لهن فعل هذا الربوت فالمسئولية تقع على الربوت نفسه.

والاعتراف للربوت الأكي بالثخصية القانونية في نظر أصحاب هذا التصور

يـشيه الاعتـراف بالشخـصية القانونيـة للشحص الاعتبـاري، وإذا كانــت الشخـصية الاعتبارية مجرد مجاز فالأمر كذلك أيضاً بالنسبة للربوت الذكي الذي يمكن وفقاً لهـا التصور أن يعترف له بحقوق والتزامات. وهذا الاعتراف ليس غريباً ؛ فالنظام القانوني

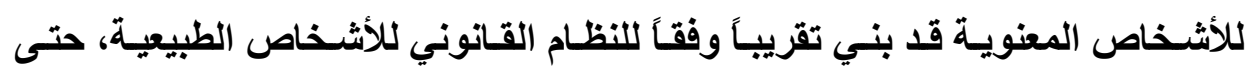
الاعتراف لها بالحقوق الأساسية.

2015. 1640 ; A.-S. Choné-Grimaldi et Ph. Glaser, Responsabilité civile du fait du robot doué d'intelligence artificielle : faut-il créer une responsabilité robotique? CCC 2018. Alerte 1

(1) « personne électronique responsable » 


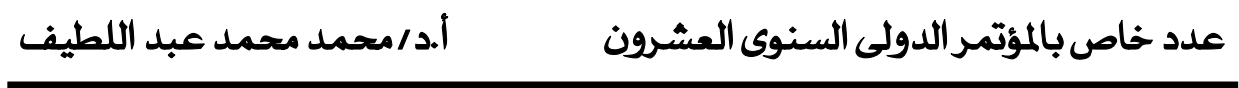

ويوضح بعض الفقه المؤيد لهذا الاقتراح حدود هذه الفكرة.فمن شأن الاعتراف

بالشخصية القانونية للربوت أن تسمح له بإبرام العقود، وبوجـه خاص عقود التأمين،

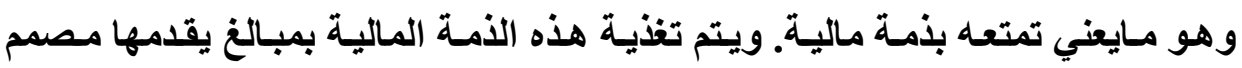

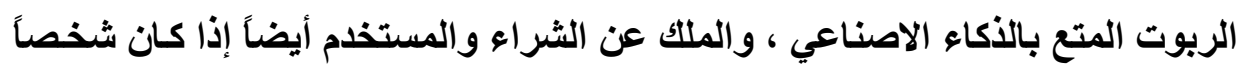

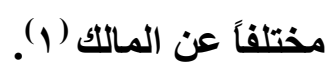

والميزة الأساسية لهذا الاقتراح هى أن تعويض ضحايا الأضرار الناجمة جراء

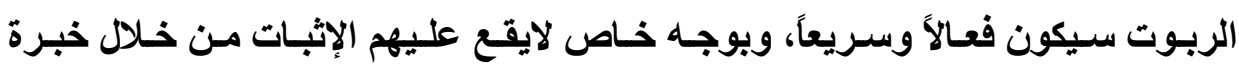

قضائية طويلة ومكلفة لشذوذ الربوت anormalite الذكي والعيب الذي بـه أو خطأ

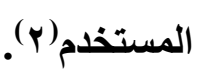

ومع ذلك فقد رفضت لجنة الخبراء التي شكلتها اللجنة الأوروبية هذا الاقتراح

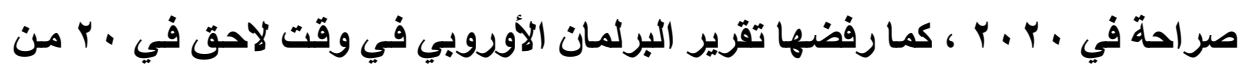

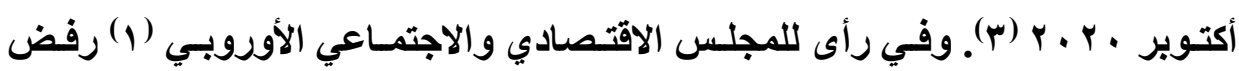

(1) G. Loiseau, M. Bourgeois, Du robot en droit à un droit des robots, JCP $G n^{\circ} 48$, nov. 2014, doctr. 1231. 16 V. not., A. Bensoussan, Plaidoyer pour un droit des robots : de la «personne morale » à la "personne robot ", La lettre des juristes d'affaires, 23 oct. 2013, n $^{\circ} 1134$; A. Bensoussan, J. Bensoussan, Droit des robots, Larcier, 2015

(2) A-S.Choné-Grimaldi et Philippe Glaser, Responsabilité civile du fait du robot doué d'intelligence artificielle : faut-il créer une personnalité robotique ? ",Contrats Concurrence Consommation $n^{\circ} 1$, Janvier 2018, alerte 1 ; A. Bensoussan et J. Bensoussan, Droit des robots, Editions Larcier 2015, p. 41 et s.

(3) D.Galbois-Lehalle, Responsabilité civile pour l'intelligence artificielle selon Bruxelle :une initiative à saluer, des dispositions à améliorer ,D.2021, p.p.87 ;Ch.Lachièze, Intelligence artificielle :quel modèle de $=$ 


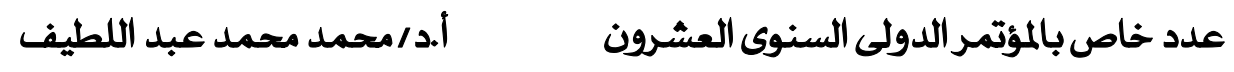

المجلس أيضاً هذه الفكرة ، وأكد على أنها يرفض منح شكل من الشخصية القانونية للربوت أو الأكاء الاصطناعي؛ بسبب المخاطر المعنويـة غير المقبولة والمتعلقة بهذه الخطوة.كمـا رفض المكتب البرلمساني للاختيـارات العلميـة والتكنولوجيـة في البرلمسان

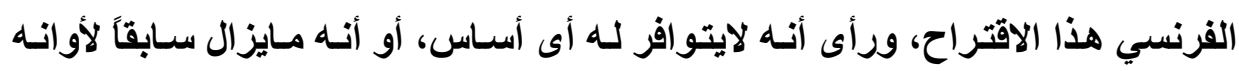

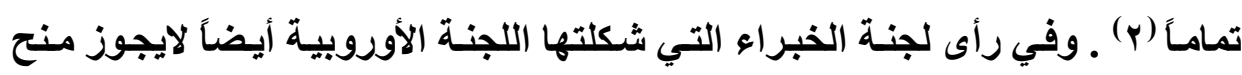

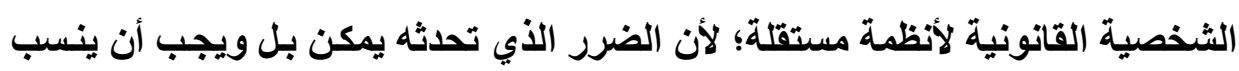
إلى أشخاص أو منظمات قائمة.

الانتقادات الموجهة إلى الاعتراف للأكاء الاصطناعي بالشخصية القانونية:

كاتت وجهة النظر القائلة بـالاعتراف للذكاء الاصطناعي بالثخصية القانونية

محلًا للنقد. ورأى الفقه فضلا عن عدم تحديد نطاق تطبيقها أنها في آن واحد خطرة وغير مفيدة(ب).

عـدم تحديـــ نطــاق تطبيـق الاعتـر اف بالشخــصية القانونيــة لربــوت الـــكاء الاصطناعي:

تثير فكرة الاعتراف للربوت بالثخصية القانونيـة اعتر اضـات تـأتي في مقمتها

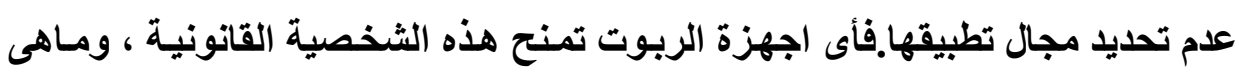

responsabilité ? D IP/IT ,2020, p.663;

(1) «Conseil économique et social européen »(CESE)

(2) OPECST, Rapport «Pour une intelligence artificielle maîtrisée, utile et démystifiée », T. 1, 15 mars 2017, p. 129.

(3) J.-R. Binet, Personnalité juridique des robots : une voie à ne pas suivre, Droit de la famille $n^{\circ} 6$, juin 2017 , repère 6 ; Ch.Lachièze, Intelligence artificielle :quel modèle de responsabilité ? D IP/IT ,2020, p.663 


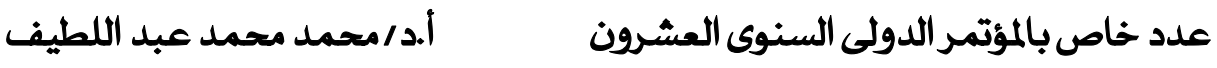

الحدود التي ينبغي فرضها بين مختلف هذه الأجهزة؟ وهل هذه الحدود ستكمن في عدم

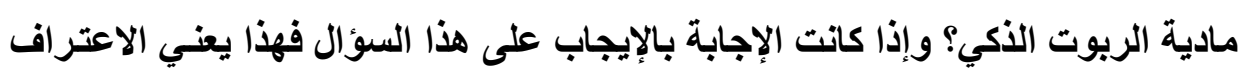
للريوت الأي لايتكون من كيان مـادي بالثخصية القانونية.وهذا التحديد يثير مشكلة كبيرة بالنسبة للبرامج الإليكترونية للمساعدة في القرار أو في قراعة الأشعة على سبيل

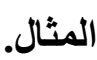
وللوصول إلى الاعتراف بالثخصية القانونية المستقلة للربوت ينبغي أن تكون

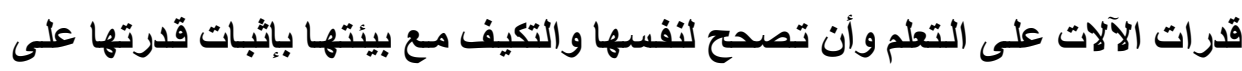
المبادرة أصبحت واضحة.

ومعييـر الاعتـر اف بالثخـصية القانونيـة للربـوت هـى الـذكاء والقدرة على الاستقلال.وهذه المعايير تثير صعوبات كبيرة كما سبق أن رأينا. الانتقادات الموجهة إلى عدم مسئولية المصممين والمنتجين ومـلاك ومستخدمي

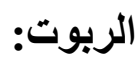

عدم إلقاء المسئولية على عاتق المصممين أو المنتجين أو مـلاك أو مستخدمي الربوت الأكي ، وخصوصاً في المجال الطبي ، ونقل هذه المسئولية على عاتق الربوت نفسه من شأنه إحداث تضارب قانوني، وربمـا يشجع هذه الفئـات إلى تصميم أو إنتاج وتذاول ربوتات ذكية خطرة، وهو ما لا يمكن السماح فيه في مجال مثل المجال الطبي. وأخطر ما يمكن أن يؤدي إليه نقل المسئولية على الربوت أنها يمكن أن يحدث

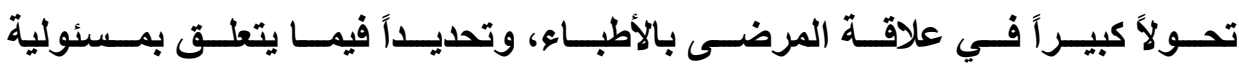
الأخيرين.فالأطباء مكلفون ببذل ما في وسعهم من أجل شفاء المرضى، وأنهم مسئولون

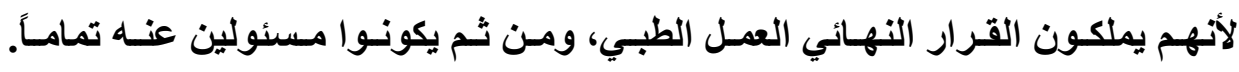
غير أن نقل المسئولية إلى الربوت سيؤدي إلى تعديل العلاقة بين المرضى والأطباء ، 


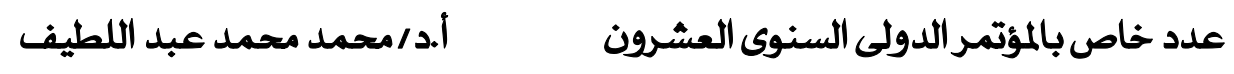

وعلى الأرجـح إلى قلب المهنـة في مجموعهـا، وهـذا مايدعو إلى رفض فكرة نقل

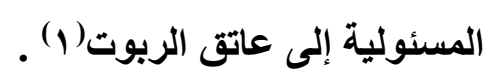

مخـاطر فكرة الاعتـراف للربـوت بالثخـصية القانونيـة على الأفكـار الأسـاسـية

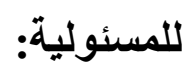

الفكرة تتميز بكونها خطرة؛لأنها تؤدي إلى إلغاء التقسيم الأساسي السائد في

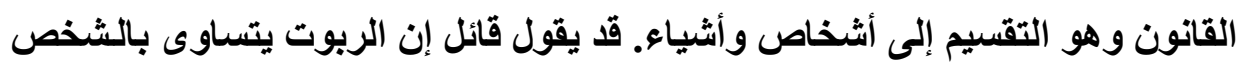
الاعتباري الأي يمكن أن يكون مسئولا.

وهنا لامكن التسليم بهذا النظر كأن هذا التشبيه في غير مصلحة هذا الرأى؛

فالشخص الاعتباري فكرة مجردة أو مجرد تشخيص قانوني لذمة مالية ، ولايتمتع بأى

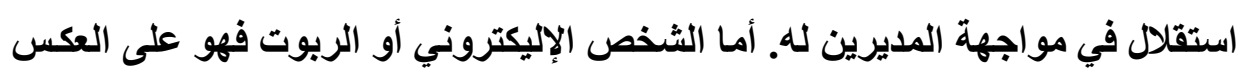
ليس مجرد كيان مجرد ؛لأنـه تشخيص قانوني للذكاء اصطناعي ، فلايسه الإمكاتيـة في التطور بطريقة مستقلة بوصفه شخصاً قانونياً.

يضاف إلى ذلك أنه على عكس الشخص الاعتباري في القانون الخـاص وهو

تجمع أثخاص، وله موضوع محدد لفالهدف من الاعتر اف بالثخصية القانونية للربوت الأكي هو تأطير النتائج القانونية لأعمال الربوت الذكي.وليس من المؤكد أن المعالجة

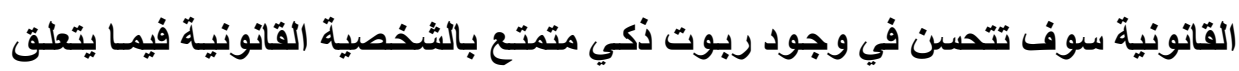
بتعويض المضرور.

(1) A.Hamoui, La responsabilité civile médicale à l'épreuve de l'intelligence artificielle, Mémoire, Master, Paris II,2020,p.49 et s. 


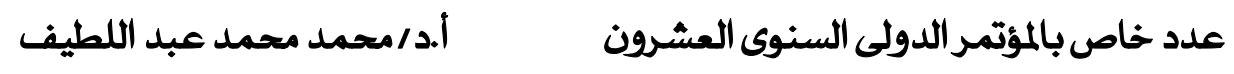

وأخيراً الاعتراف بالثخصية القانونية للربوت يمكن أن يؤدي مستقبلاً أيضاً

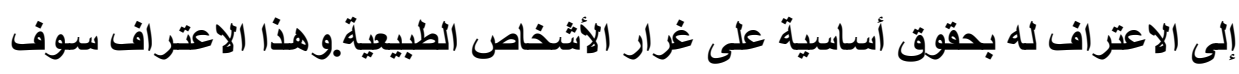

يثير مشكلات حادة أكثر من تلك التي تثور بالنسبة للأشخاص الاعتبارية. وهل يمكن أن الن

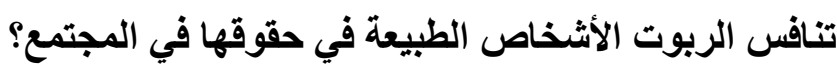

عدم فائدة فكرة الاعتر اف للربوت بالشخصية القانونية:

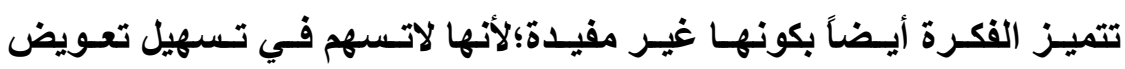

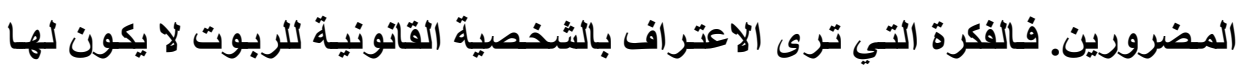

فائدة إلا إذا كانت تتوافر له ذمة مالية، ويغطى بتأمين المسئولية.ويجب من ثم أن يمثل

الربوت قانوناً شخص مثل المنتج أو الكالك أو المسنخدم، فيبرم نيابة عنه العقود. وهنـا

يحق أن نتساعل لم لا يكون هذا الشخص الطبيعي هو المسئول بدلاً من هذا الالتفـاف

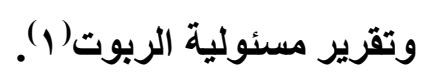

فكرة التشخيص القـانوني للربوت كمـا تقول محكمة استتئناف بـاريس لا تفعل

سوى نقل المشكلة، بمعنى أن الأشخاص الذين يقع عليهم المساهمة في تغذيـة الذمـة

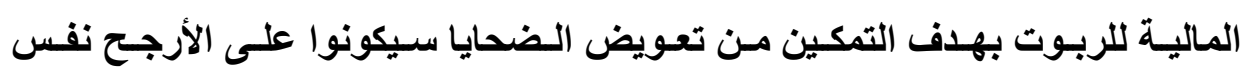

الأثخاص الذين ستنعقد مسئوليتهم في حال تطبيق القواعد العامة في المسئولية(ب) .

(1) J.-S. Borghetti, L'accident généré par l'intelligence artificielle autonome, JCP 2017, $\mathrm{n}^{\circ}$ spécial, Le droit civil à l'ère numérique, spéc. $n^{\circ} 41$; G. Loiseau, La personnalité juridique des robots, une monstruosité juridique, préc .

(2) CA de Paris, Rapport du groupe de travail sur « La réforme du droit français de la responsabilité civile et les relations économiques ", 25 juin 2019, p. 108 


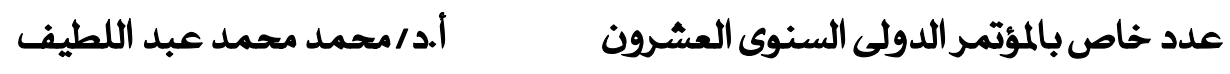

وأخيراً يؤدي نقل المسئولية إلى الربوت إلى مشكلة أخرى تتعلق بإعاقة وظيفة

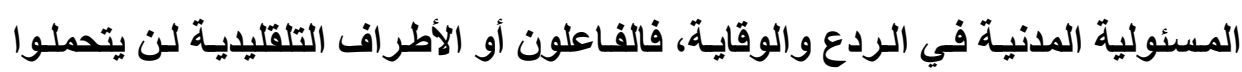

على الأرجح عبئ دعاوى المسئولية التي ستوجه إليهم.

باختصار الأكاء الصناعي هو شئ يكون شخصاً ما مسئولاً عنه.

\section{الاطلب الثاني}

نوع المسئولية عن الذكاء الاصطناعي

إذا كان الربوت الأكي أو الأكاء الاصطناعي شيئًا أو مـالاً تجاريـاً ، كمـا أسلفنا،

فيمكنه إحداث أضرار، وهنا يثار التساؤل عن نوع المسئولية عنه أو أساسها.

وفقاً للفقه تكون المسئولية عن الأكاء الاصطناعي إمـا مسئولية شخصية عن

خطأ الأطباء، أو مسئولية عن فعل الأشياء ، أو مسئولية عن المنتجات المعيبة.

مسئولية شخصية قائمة على الخطأ:

يمكن بحث المسئولية الثخصية عن الخطأ من خلال البحث عن معايير جديدة

مثل تعقد النظـام ودرجـة مسـاعدته في اتخـاذ القرار وإمكانيـة التـخل التي يعهد بهـا

$$
\text { للمستخدم. }
$$

ويجب وفقاً للقواعد العامـة إثبـات الخطأ ، والضرر، وعلاقـة السببية. وفيمـا

يتعلق بالخطأ بوجه خاص فيجب إثبات خطأ المستحدم في الاستعمال، أو خطأ المنتج في برمجة الربوت، وسـواءً كـان الخطأ عمدياً أو غير عمدي.غير أن المشكلة تكمن في صعوبة الإثبات من ناحية، ومن ناحية أخرى إذا ارتكب الربوت الأكي خطأ باتخاذ قرار دون وقوع سلوك متنازع فيه من جانب المالكك أو المستخدم أو المنتج فلايمكن حينئذ

تطبيق المسئولية القائمة على أساس الخطأ. 
وفي المجال الطبي يثار التساؤل: ماذا عن الطبيب الذي لم يمتثل في تشخيصه لتشخيص الاكاء الاصطناعي الأي تبين أنه ضار بالمريض؟ هل هلئ يجب أن يكون الطبيب

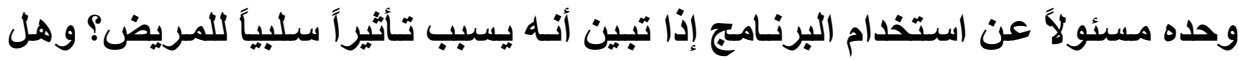

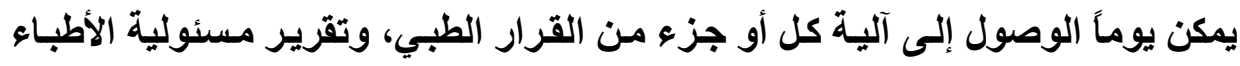

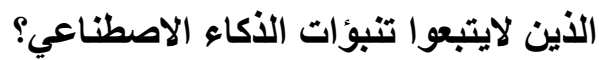

هـل يمكن أن تكـون المسئولية عـن الـذكاء الاصـطناعي مسئولية عـن فعل

إذ كان برنامج المساعدة في التشخيص الطبي يقترح على الطبيب قراراً خطّاً

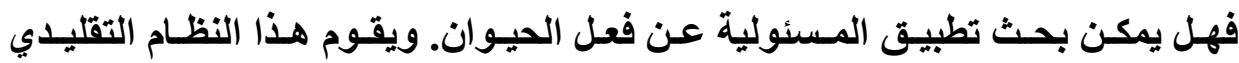

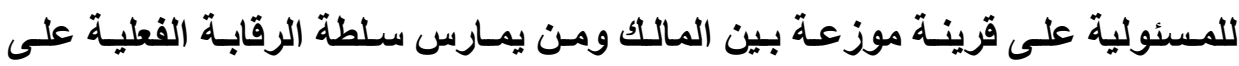

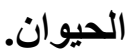

ويرى أنصار هذا الرأى أنهله على الرغم من الاختلاف بير الربوت والحيوان إلأنهـ يمكن تطبيق نظام المسئولية عن الحيوان على الربوت، ووفقاً لـه يكون مالكت

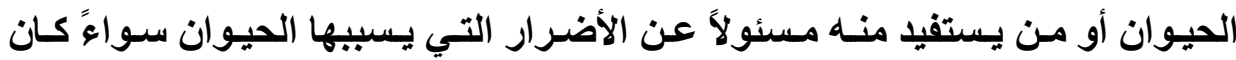

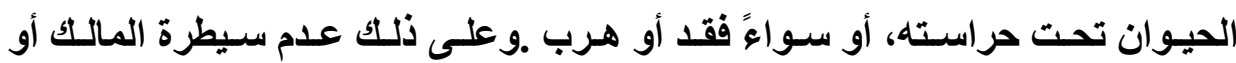

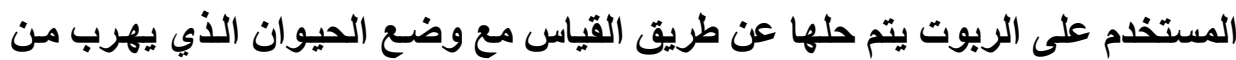

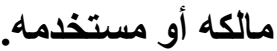

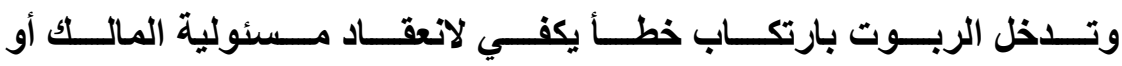

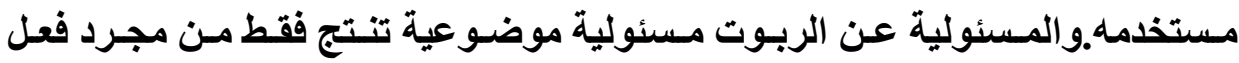
الربوت، وحارس الريوت هو المسئول عن الضرر أو الحسادث، وفكرة الخطأ همـا غير

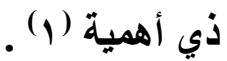

(1) A.Mendoza-Caminade, Le droit confronte à l'intelligence artificielle des robot :vers l'émergence de nouveaux concepts juridiques ? D.2016, p.445. 


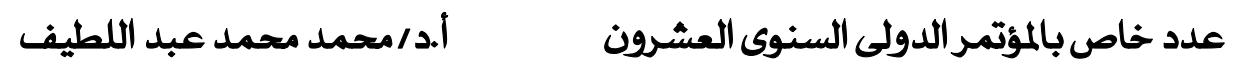

وهذا الحل يصطدم بفرضية تثير الاعتر اض وهى تشبيه الآلة بكائنـات حية

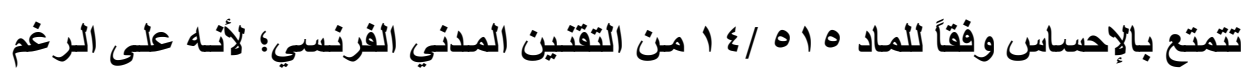
من أن الحيوان يـخل في أسـرة الأموال إلا انـهـ يشكل طائفة قانونيـة خاصـة يستحق حماية من القانون الجنائي.

والحيوان لايتمتع بالثخصية القانونية على الرغم من ذاتيتهـ الطبيعيـة. وكمـا

يقول البعض إذا لم يكن ممكنا التقارب بين الربوت والإنسان فالأمر كذلك أيضاً بالنسبة لإله

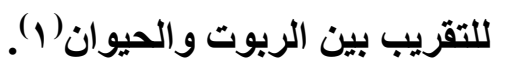
المسئولية عن الأكاء الاصطناعي مسئولية عن فعل الأشياء:

يرى بعض الفقه أن المبدأ العام للمسئولية عن فعل الأشياء (ץ) المنصوص

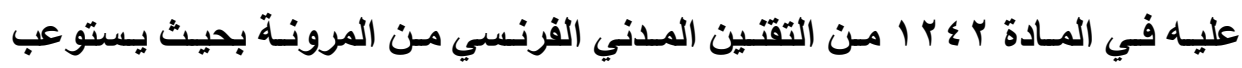
الأضـرار التـي يحـثها الــكاء الاصـطناعي. ومـؤدى هـذا التطبيق أن حـارس الــكاء

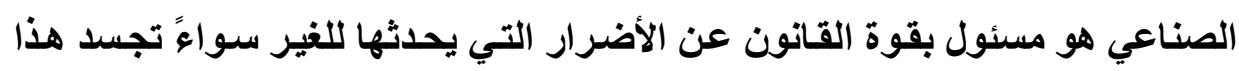
الذكاء ماديـاً في ربوتـات أو ظل مجرد بـرامج إليكترونيـة. وعلى ذلتك إذا قامـت الآلـة

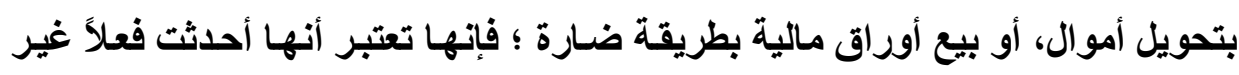
عادي، ويعتبر مستخدمها حينئذ حارساً مادام أعطى أوامر للآلة(ب).

(1) L.Mazeau, Intelligence artificielle et responsabilité civile : le cas de logiciels d'aide à la décision en matière médicale, Rev. pratique de la prospective et de l'innovation, 2018,p.38 et s.

(2) « Responsabilité du fait de chose».

(3) F.G'Sell, Vers L'émergence d'une responsabilité numérique, D.IP /IT, 2020, p.153. 


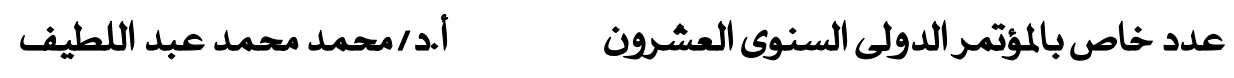

ولايخفى هـا الفقهـ أن تطبيق المسئولية عن حراسـة الأثـياء على الـكاء الاصطناعي يثير نوعين من الصعوبات.

أمسا النوع من المشكلات فيتعلق بمدى تطبيق المسئولية عن فعل الأشياء على الأشياء غير المادية. فالأكاء الاصطناعي ليس بالضرورة مدمجاً في أشياء مادية.غير أن عموم مبدأ المسئولية عن فعل الأشياء الذي لا يقيم تمييزاً بين الأشياء الماديـة والأثياء غير المادية. ينبغي أن يقم إجابة بالإيجاب ( ) . وأمسا النـوع الثـاني مـن الـصعوبات فهـو كيفيـة تحديــ الحسارس عـن الــكاء الاصطناعي. فالحارس وفقاً لأحكام القضاء هو الشخص الذي لـه استعمال ، وتوجيه،

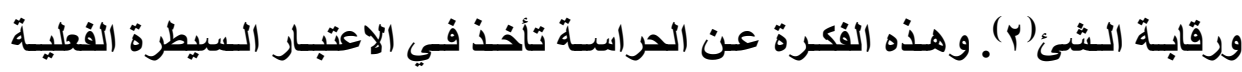
maîtrise effective ومع ذلك لايخلو تطبيق هذه الفكرة الماديـة للحراسـة على الذكاء الاصطناعي من بعض الصعوبات؛ لأن قدرات هذا الذكاء تفتح لـه قدراً من الاستقلال في العمل ، الأمر الذي يجعله لا يخضع بالمعنى الضيق لسيطرة المستخدم ؛ لنـه يتمتع باستقلالية في القرار؛ بسبب قدرتهـ المعرفيـة والتعليميـة. ونظراً لأن أعماله ليست محددة سـلفاً بواسطة برامج إليكترونية ، كما في الماضس، فسوف تقلت الآلة من تحكم الإنسان، وهو ما يعني استبعاد اللجوء إلى فكرة الحراسة.

(1) G. Loiseau et M. Bourgeois, Du robot en droit à un droit des robots, préc., spéc. $\mathrm{n}^{\circ} 12 ;$ Ch. Lachiéze, précité .

(2) Cass., ch. réun., 2 déc. 1942, DC 1942, p. 25, note G. Ripert ; S. 1941. I. 217, note H. Mazeaud. 


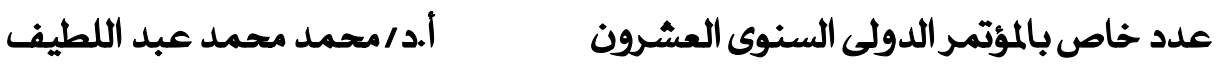

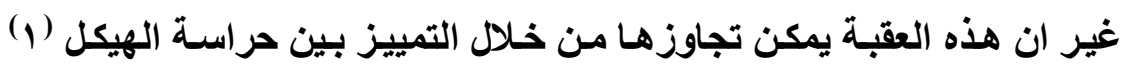

وحراسة المسلك (ץ) فالمنتج يظل هو حارس الهيكل ، بينمـا المستخدم ليس إلا مجرد حارس المسلك.

باختصار ينتهي بعض الفقه إلى أنه ليس ضرورياً بنـاء نظام جديد للمسئولية

عن الأكاء الاصطناعي، وأن المبدأ العام للمسئولية عن فعل الأثياء مرن إلى درجة إلى استيعاب المخاطر الجديدة المتعلقة بالأكاء الاصطناعي (ب) . الرأى القائل بالصفة التكميلية لنظام المسئولية عن فعل الأشياء:

يـرى بعض الكتابأنسه يمكن الاسـتعانة بالقواعد العامـة للمسئولية عن فعـل

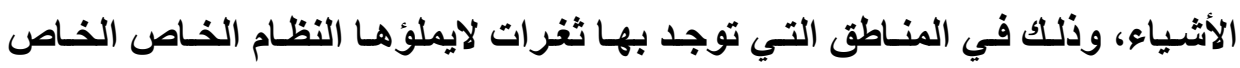

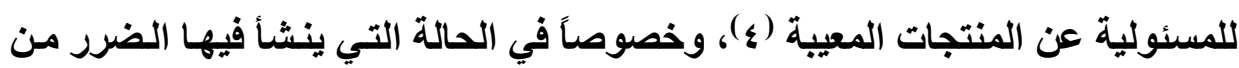
التشغيل غير العادي لنظام المساعدة في القرار. ففي هذه الحالة تضع المسئولية عبء التعويض على عاتق حارس الشئ، وهو من له سلطة الاستعمال، أو التوجيه، أو الرقابة. وحتى يمكن رسم حدود هذه المسئولية في سياق المساعدة في القرار يمكن

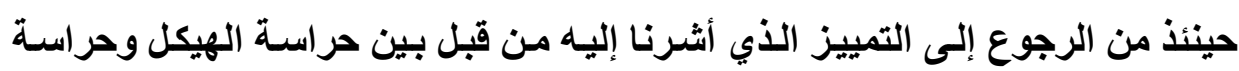
السلوك. ومع ذلك قد يكون هناك ما يدفع إلى اعتبار المساعدة في القرار قد تطورت بما

(1) « Garde de structure ».

(2) « Garde de comportement».

(3) Ch. Lachiéze, précité.

(4) L.Mazeau, précité. 


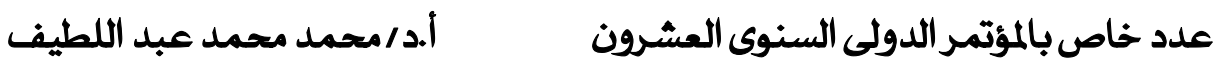

فيه الكفاية لتحقيق استقلالية كافية، مما يجعله واقعاً خارج سيطرة المستخدمين، وهو ما يؤدي إلى وجود تعارض بين نظام المساعدة والمسئولية عن فعل الأشياء.

وفي الحقيقة يمكن لنظم المساعدة في القرار تنفيذ عدد من المهام في استقلالية

نسبية، لكنها تظل دائماً تحت سيطرة المستخدم أو المصمم ، لأن هؤلاء يمكنهم دائمـاً إيقاف تثغيلها، او عدم اتباع التوصيات.ومن هنا يمكن أن تقع مسئولية مخاطر الهيكل المتعلقة بتصميم نظام المساعدة في القرار على الصانع وفقاً لتطبيق قواعد المسئولية

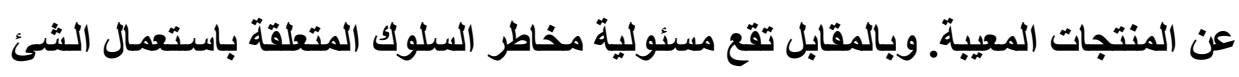
يمكن أن يقع عبئ التعويض على المالك ، المستشفى على سبيل المثال، أو الطبيب مستخدم الشئ في مواجهة المريض. وهذا التمييز ليس مجرداً ، لأنسه يمكن أن نكون مخاطر السلوك راجعة في الأصل إلى مخاطر هيكلية( ). مدى تطبيق المسئولية عن المنتجات المعيبة: لاتبدو القواعد العامة في المسئولية كافية لمواجهة الأبعاد المتميزة لاستخدام الذكاء الاصطناعي في مجـال المساعدة في القرار ، وخصوصاً للمساعدة في قرار التشخيص الطبي. توجد نظم خاصة للمسئولية المدنية تأتي في مقدمتها المسئولية عن المنتجات المعيبة (ץ) الأي تبته المادة ه ؛ ب ا والمواد التالية من التقنين المدني ، تطبيقاً للتوجيه

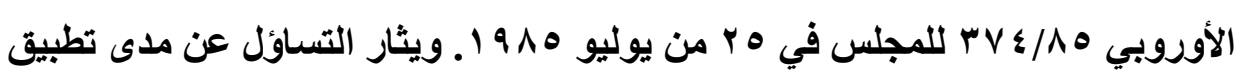
هذا النظام من المسئولية على الذكاء الاصطناعي.ويرى البعض أن قواعد المسئولية

(1) L.Mazeau, précité.

(2) « Responsabilité du fait des produits défectueux ». 


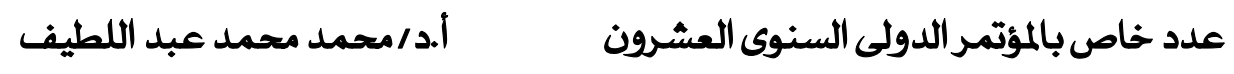

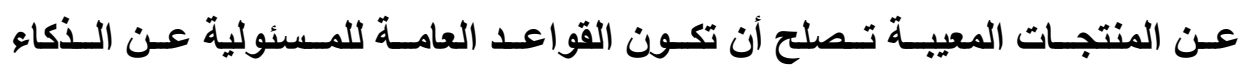
الاصطناعي( () وعلى ذلك يكون منتجـاً معيبًا برنامجاً تسبب في ضرر ؛لأنه لا يقدم السلامة التي المتوقعة منه قانوناً.

ويتميز نظام المسئولية عن المنتجات المعيبة بتركيز المسئولية على المنتج ،

ويفهم المنتج producteur على أنه الصانع fabricant ـ فالأضرار يمكن أن ترتبط

بعيب في الريوت الذكي.ويجوز للمضررين إذن مقاضاة الصانع لعيب في التصميم.

ويتميز نظام المسئولية عن المتجات المعيبة بأنه يقيم مسئولية موضوعية دون

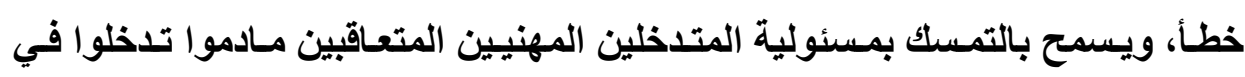
عملية إنتاج أوتوزيع المنتج.وهنـا يبدو في نظر البعض أن القانون الوضعي يتوافق

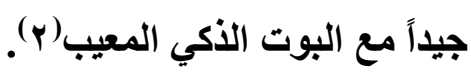

ويثير تطبيق هذا النظام الخاص على الأضرار الناشئة عن الذكاء الاصطناعي

بعض الصعوبات مرجعها أيضاً إلى التساؤل عن تطبيقهـ على الأشياء غير الماديـة. والإجابة في نظر الفقه هى بالإيجاب ؛ نظراً لأن التوجيه الأوروبي ، والقانون الصـادر

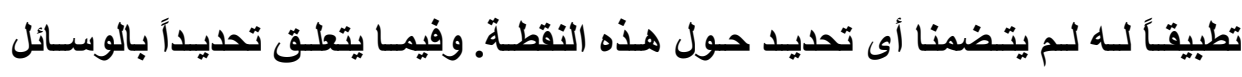

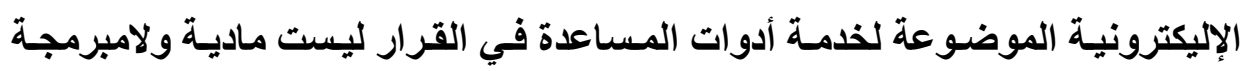
تمامـاً على عكس النمـوذج الذّي كـان محسلاً للتفكير في أثنـاء وضـع التشريع الخـاص

(1) G. Loiseau et A. Bensamoun, La gestion des risques de l'intelligence artificielle, JCP 2017 1203

F.G'Sell, Vers L'émergence d'une responsabilité numérique, D.IP /IT, 2020, p.153 .

(2) A.Mendoza-Caminade, précité. 


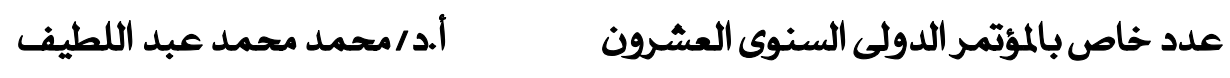

بالمنتجات المعيبة.ويمكن أن تنعقد مسئولية مبرمج برنـامج المساعدة في القرار مثل

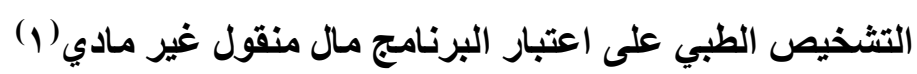

ويوجد تساؤل آخر هو كيفية تقدير شرط العيب في المنتجات، خصوصاً أن تعقد

تثغيل الذكاء الاصطناعي يمكن أن يثير عقبة تتعلق بوجه خاص بالإثبات.

وأخيراً ووفقـاً لهــا النظــام يحـوز الإعفــاء مـن المسئولية فـي الحالــة التـي

تكون فيها حالـة المعـارف العلمية والتقنيـة في الوقت الذي طرح فيه الصانع المتتج

للتداول لا تسمح بالكشف عن وجود هذا العيب(المسادة ه ؛ ب ا / ـ 1 من التقنين المدني

$$
\text { (الفرنسي). }
$$

وهذا السبب للإعفاء المسمى مخاطر التنمية (ب) ، يسمح للمنتج بالإعفاء من

المسئولية بإثبـات أنـه كـان يجهل وقت طرح المنتج للتداول بوجود العيب، وأن هذا الجهل كان حتمياً ؛ نظراً لحالة المعارف العلمية والتقتية في ذلك التاريخ.

وتطبيق هذا الإعفاء على الأكاء الاصطناعي الذي يتميز بالتشغيل المعقد كمـا

ذكرنا وبقرته على التصرف بشكل مستقل يعني قبول الإعفاء من المسئولية على نطاق

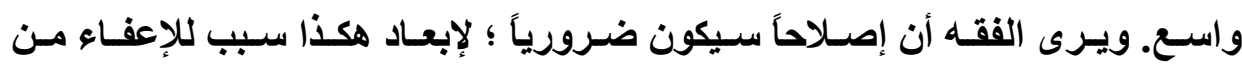
المسئولية فيما يتعلق بالأضرار التي يحدثها الأكاء الاصطناعي(ب).

ومن الوارد جداً أن النظام يتطور في الفترة من تداوله إلى ما قبل وقوع الحادث

بعدة أشهر أو عدة سنوات مثل تعديل السلوك أو إضافة ميزات وظيفية جديدة من خلال

(1) «Bien meuble incorporel».

(2) « Risque de développement ».

(3) Ch. Lachiéze, précité. 


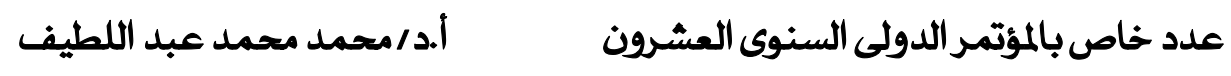

تنزيـل بـرامج خاصـة. عـلاوة على ذلـك يمكن أن يعمـل برنـامج المسـاعدة في القرار كصندوق أسود ذات مدخلات ومخارج ولكن ليس نظاماً للتفكير.

وإذا كاتت هذه النتيجة عادية في نظم المعلومات الاستراتيجية التي تعتمد على

مستودعات بيانات كبيرة لايؤدي الخطأ فيها إلا إلي عواقب محدودة ، إلا أن الأمر على

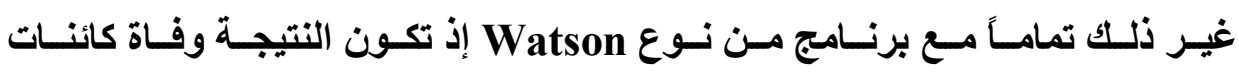
بشرية.يضاف إلى ذلك أن هذه البرنـامج تشير إلى تـأخير طفيف بالمقارنـة بالحالـة

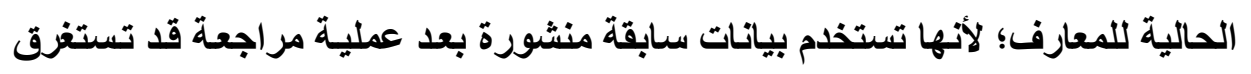

$$
\text { شهورًا. }
$$

وفي هذا السياق يصبح بحث مسئولية الشركة المصنعة التي لم يعد تطوير

المنتج مسئوليتها وحدها أكثر صعوية.ولهذا السبب يكون تحليل فكرة عيب المنتج

بطريقة مجردة.ومن ثم يكون معيباً المنتج الذي لايقدم الأمن الذي يمكن توقعه قانوناً.

تطبيق نظام المسئولية في قانون ه 19 :

أصبـح ممكنـاً بفضل الـكاء الاصـطناعي تسبير مركبـات أرضسية بمحركـات

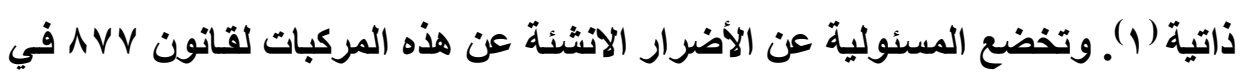
ه من يوليو ه19 1 ، ، وهو القانون المعروف بقانون Badinter ـ ويقيم هذا القانون

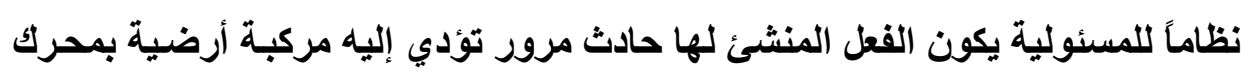

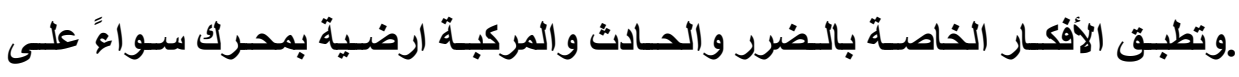
المركبات الأتية أو المركبات التي يقودها شخص طبيعي.

(1) « Véhicule autonome». 


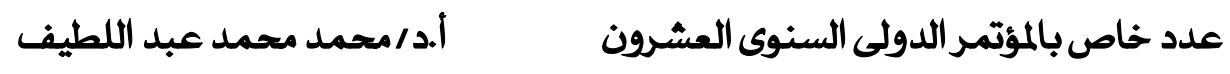

والقدرة الأتية لهذا النوع من المركبات لاتزال محدودة؛ نظراً لأن الشخص الموجود في المركبة هو الأي يعي توجيهات لها، ومن ثم يعد مسئولاً في الحالـة التي

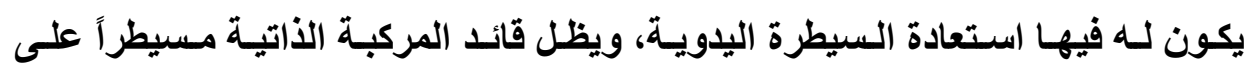

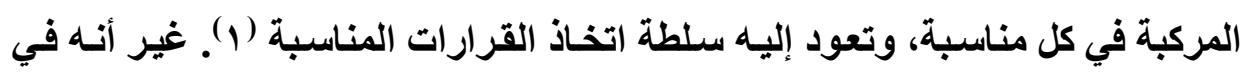
المستقبل يمكن أن توجد أنظمة قيادة تتولى السيطرة تماماً على المركبة، وحينئذ يكون تطبيق أحكام قانون 191 1 غير ممكن. وفي هذه الحالـة يثار التساؤل عمـا إذا كـان المنتج يكون هو المسئول عن الضرر الذي أحدثته المركبة.

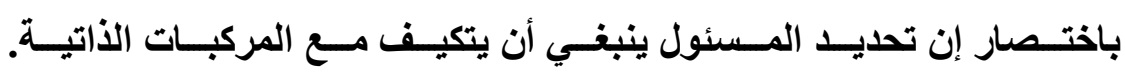
فالمـادة الثانية من هذا القانون تنص على أن المسئول هو القائد conducteur أو الحارس gardien للمركبة التي تسببت في الحسادث. وهذه الأفكار ليست متلائمـة مـع المركبات الذاتية التي تقع قيادتها على نظام تابع للأكاء الاصطناعي. وأخيراً حتى ولو احتفظ مستخدم المركبـة بـبعض إمكاتيـات للتصرف، خصوصاً بعـدم تفعيل القيـادة

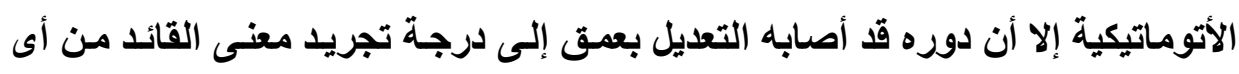
مضمون. باختصار يمكن تطبيق النظم الخاصة للمسئولية على مخاطر الذكاء الاصطناعي مع بعض التعديلات التي تبجو مهمة.

(1)M. Monot-Fouletier, Véhicule autonome : vers une autonomie du régime juridique applicable ? D.2019, p.129. 


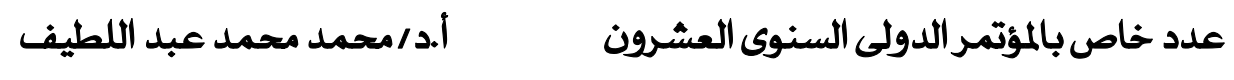

\section{المبحث الثاني}

\section{المسئولية عن الذكاء الاصطناعي وقانون العمل}

تأثر قانون العمل بدوره كثيراً باستخدام نظام بالذكاء الاصطناعي، وخصوصاً

في مجال التشغيل، وتنظيم العمل، وأخيراً المسئولية.

وفي مجسال المسئولية بوجـه خـاص يثير اسـتخدام الذكاء الاصطناعي عدة

تساؤلات خاصة عن تحديد المسئولية عن استخدام نظام الذكاء الاصطناعي، وبوجه خاص من يكون مسئولاً عن الضرر الذي يحدثه هذا الاستخدام في مواجهة الغير وفي مواجهة العامل نفسه. مسئولية استخدام انظمة الأكاء الاصطناعي في مواجهة الغير: الفرض ان العامـل باستخذام نظـام ذكـاء اصطناعي وضـعه صـاحب العمل في خدمته مثل برنامج للمساعدة في القرار قد أحدث ضرراً للغير. ومن ثم يكون للمضرور وفقاً للقواعد العامة مطالبة صاحب العمل بالتعويض. مدر.

ويستند الفقه إلى أن أساس دعوى المسئولية هنا في مواجهة صاحب العمل هو المسئولية عن فعل الشئ المنصوص عليها في المادة ب ع ب / / من التقتين المدني. وفي سبيل تأييد هذا الرأى يرى الفقه أن رابطة التبعية ( () لاتمكن العمل من

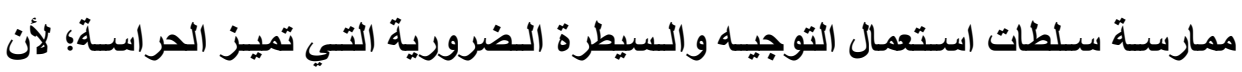
ممارسة هذه الطات يفترض استقلالاً حقيقياً من جانب العامل الحارس التي لايتمتع بها (1) « Rapport de subordination ». 


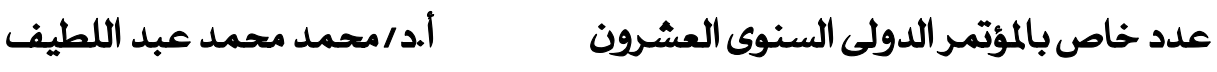

في حالة الأكاء الاصطناعي. ففي الحالة التي يقوم فيها العامل بالاستعانة بنظام ذكاء اصطناعي لإنجاز مهمته لايمكن وصفه بالحسارس. ومن ثم إذا حدث ضرر تسبب فيه العامل ؛لاستعانته بنظام ذكاء اصطناعي فلايجوز للمضرور توجيه دعوى المسئولية استناداً إلى مسئولية المتبوع عن أفعال تابعه، وإنما يوجهها إلى صاحب العمل استناداً إلى المسئولية عن فعل الشئ؛ بوصفه حارساً لنظام الذكاء الاصطناعي مصدر الضرر. وهذا الرأى يفترض، كما يقول البعض (1)، تجاوز نوعين من الصعوبات. أما النوع الأول فهو إقامة دليل إلإثبات على أن صاحب العمل هو حارس نظام الأكاء الاصطناعي أى أنـه يمسارس سلطات الاستعمال والتوجيه والرقابـة. صحيح أنها يمكن ان تكون ملكية نظام الأكاء الاصطناعي قرينة ، لكن يمكن قلبها. وهنـا يلجـأ الفقه الفه إلى التمبيز الذي سبق أن أشرنـا إليه بين حراسـة السلوك وحراسـة الهيكل ومـؤداه أن مالك النظام يحتفظ فقط بحراسة السلوك ، بينما المصمم يحتفظ بحراسة الهيكل. وهذا التمييز لايبدو فعالاً دائماً عندما يتعلق الأمر بتحديد مـا إذا كان قرار اتخذ

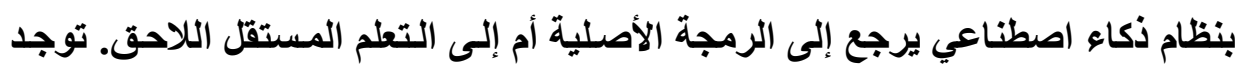
كثير من العقبات التي يمكن تجاوزها ، حتى ولوكاتت تؤدي بالكاد إلى تعويض الأضرار الناشئة عن استخدام نظام الأكاء الاصطناعي. وأما النوع الثاني فهو أنه ويصرف النظر عن حارس نظام الذكاء الاصطناعي المالك أو المصمم ، فينبغي التسليم بأن المسئولية المدنية عن فعل الأشياء تطبق أيضاً على الأشياء غير الماديـة وهى هنـا نظام الذكاء الاصطناعي.وهذا النظام ينكون من ربوت أى شئ مادي. غير أنـه أيضاً يتكون غالباً من شـئ غير مـادي. ويبدو أن فكرة

(1) M.Poumarède, Intelligence artificielle, responsabilité civile et droit du travail. Droit social, 2021, p.152. 


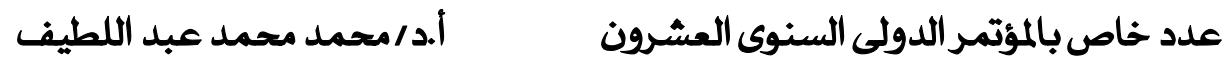

الحراسة في نظر الفقه تنصرف إلى الأثياء غير المادية والأشياء المادية على حد

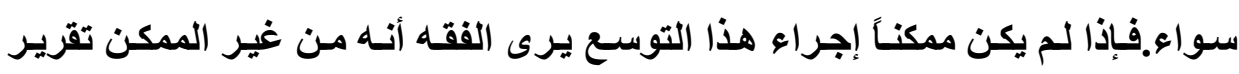
مسئولية صاحب العمل عن نظام الأكاء الاصطناعي المستخدم من العامل. والمسئولية عن نظام الذكاء الاصطناعي في مواجهة الغير تعترضها صعوبة

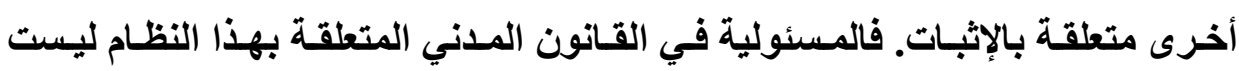
موضوعية، وفي حالة العودة إلى المسئولية القائمسة على الخطأ، وهو أمر لايستطيع المضرور تقديم الاليل على الخطأ، ويوجه خاص يتطلب الإثبات توافر معلومـات بسبب تظور نظام الأكاء الاصطناعي وتكون متعلقة بالتعلم apprentissage لشرح سلوك

الأكاء، وأيضاً معرفة أصل بيانات التعلم حتى يمكن إسناد الخطأ. المسئولية عن الأكاء الاصطناعي في مواجهة العامل: يمكن أن يستخدم الأكاء الاصطناعي من جاتب صساحب العمل من أجل تحسين سلامة العاملين، وعلى سبيل المثاليمكن استخدام أجهزة الربوت للقيـام بأعمـال خطرة، أو وضع برامج تسهم في اتخاذ القرار. ويمكن مع ذلك أن يؤدي إلى إحداث أضرار لهم ، ومن ثم يجب تعويضها. إن طبيعة قانون العمل تتطلب منح العاملين حماية خاصة في تنفيذ عقد العمل.وهذه الطبيعة يجب أن توجـه الحلـول الخاصـة بكيفيـة تعويض العامـل عن أضـرار استخدام الـذكاء

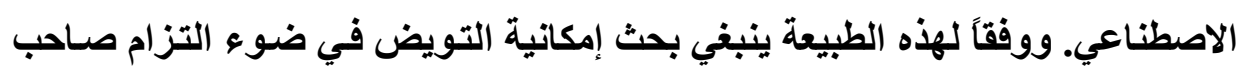
العمل بسلامة العماملين ، وهو في الأصل التزام بنتيجة.غير أنه يجب البحث أيضاً عن كيفية تعويض العامل في الحالات التي يكون فيها التزام صاحب العمل بسلامة العاملين التزامًا بوسيلة. وتوجد حالات أخرى يتعين على العامل توجيه الدعوى إلى منتج نظام الأكاء الاصطناعي. 
التزام صاحب العمل بسلامة العاملين في مواجهة نظام الأكاء الاصطناعي: ليس من المستبعد أن تحدذ أنظمة الذكاء الاصطناعي ضرراً بالعامل. وعلى سبيل المثال من الصعب استبعاد أى حادث في مجال النقليكون مصدره نظام الذكاء الاصطناعي على الرغم من التظور الكبير الذي حدث لهذا النظام في مجال النقل. وإذا كانت نظم الأكاء الاصطناعي تهاف إلى تطوير الصيانة التنبؤية، وتحسين حركة المركبات، أو تحسين الخدمات اللوجستية إلا أنسه لايمكن استعاد حوادث العمل

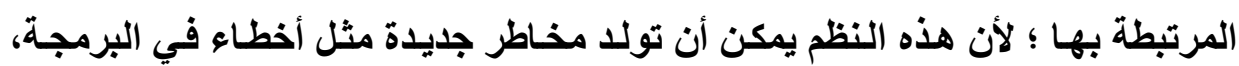
والتوتر، وانخفاض اليقظة ، وتؤدي بدورها إلى حوادث عمل وأمراض مهنية تصيب

وبطبيعة الحال يجب تحقيق الوقاية من هذه المخاطر الجديدة في إطار نصوص قانون العمل التي تلزم صاحب العمل باتخاذ التدابير اللازمـة لضمان السلامة ، وحمايـة الـصحة الجسمانية والعقليـة للعـاملين مـن خـلال الإجـر اءات الوقائيسة، والمعلومـات،

والتدريب، ووضع تنظيم ووسائل مناسبة في مواجهة نظم الذكاء الاصطناعي (1). وهذه الالتزامات التي تقع على صاحب العمل أصبحت أساسية بمعنى أنها ترسم إطار الالتزام بالسلامة على صـاحب العمل في مواجهة عامليه. ومن هنـا جـاء قضاء

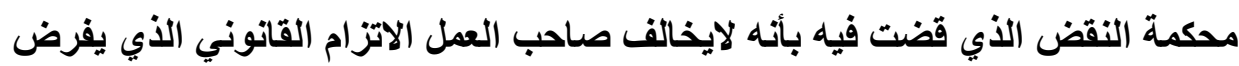

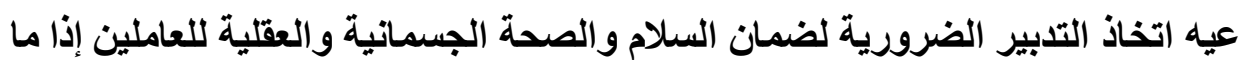
أثبت اتخاذ جميع التدابير المنصوص عليها في تقنين العمل(ץ).

(1) Articles L.4121-1, L.4121-2 Code du travail.

(2) Soc., 25 nov. 2015, $n^{\circ}$ 14-24.444, Air France (Sté), Bull. civ. V, $n^{\circ}$ 234, D. 2015. 2507 ; ibid. 2016. 144, chron. P. Flores, S. Mariette, E. Wurtz et $=$ 


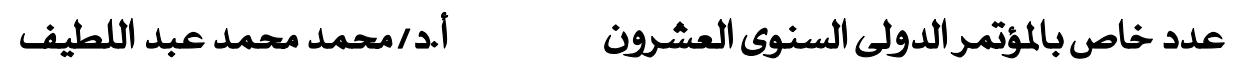

ويبدو كما يقول بعض الكتاب أنه في ضوء هذا القضاء يكون من الصعب تقرير

مسئولية صاحب العمل مالم نعتبر أن الضرر الناجم عن نظام للذكاء الاصطناعي يعني

بذاته وجود خطأ من صاحب العمل الأي اختار تطبيق هذا النظام ( ).

وبالتأكيا تستبعد مسئولية صاحب العمل في كل مرة يتسبب فيها نظام الذكاء

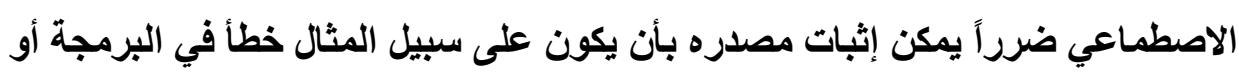

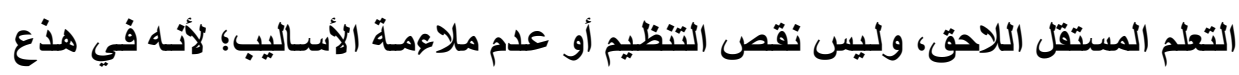

الحالات لايكون صاحب العمل قد ارتكب أى خطأ

المسئولية المدنية لمنتج نظام الذكاء الاصطناعي:

إذا لم يكن ممكناً رفع دعوى التعويض على صساحب العمل ، يجوز للعامل رفع

الدعوى ضد مصمم نظام الأكاء الاصطناعي.

ونظراً لعدم وجـود نظـام خـاص بالمسئولية يطبق على مشظلي نظم الذكاء

الاصطناعي يكون على العامل اللجوء إلى نظام المسئولية عن المنتجـات المعيبة وفقاً

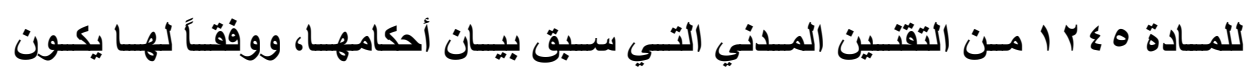

المنتج مسئولاً عن الأضرار الناجمة جراء عيب في المنتّج سواءًً ارتبط مـع المضرور

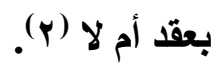

N. Sabotier ; ibid. 807, obs. P. Lokiec et J. Porta; Dr. soc. 2016. 457, étude P.-H. Antonmattei.

(1) M.Poumarèdes, précité..

(2) M.Poumarèdes, précité.. 


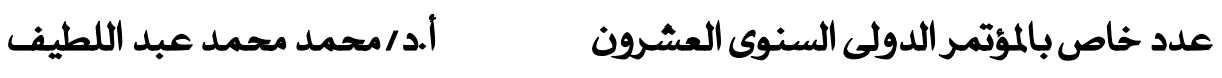




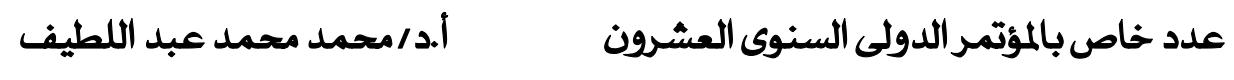

\section{المبحث الثالث}

\section{المسئولية عن الذكاء الاصطناعي في القانون المام}

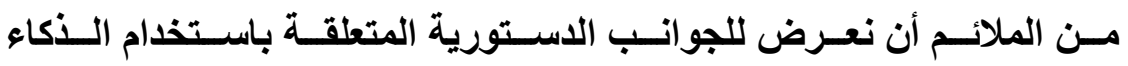

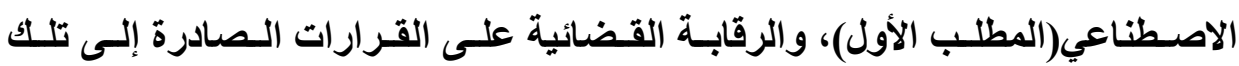
التقنية(المطلب الثاني)؛ نظراً لأهمية هذه الجوانب في مجال المسئولية(المطلب الثالث).

\section{المطلب الأول}

\section{البوانب الدستورية لاستفدام الذكاء الاصطناعي في هجال القرارات الإدارية}

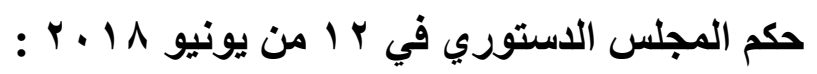
قضى المجلس الاستوري بلستورية المادة إ من القانون الأي يسمح للإدارة باتخاذ قرارات إداريـة فرديـة لها صفة آلية ؛ نظراً لأن السلطة اللانحية تحدد بنفسها القواعد والمعايير التي تغذي المعالجة الحسابية algorithme ، ومن ثم لم تتحلى عن

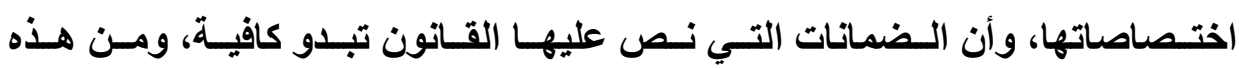
الضمانات:منع الطعن الحصري على المعالجة الحسابية في حالة توافر معلومـات ذات حساسية، وفرض الإلزام بالإثارة إلى الأساس الحسابي للقرار، وإمكانية الحصول على الخصائص الرئيسية لتنفيذها، وإمكانية ممارسـة طريق الطعن الإداري والقضائي ضد الإسل القرار، وأخيراً إلزام المسئولين عن المعالجة الحسابية التحكم في المعالجة وتطورهـا؛ 


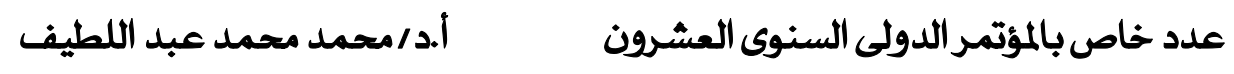

حتى يمكنهم أن يشرحوا بالتفصيل وفي شكل ميسر للشخص المعني الطريقة التي تم إعمالها للمعالجة في مواجهته( (1).

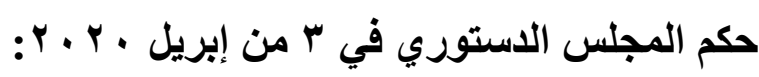

في هذا الحكم يكرس المجلس الاستوري الحق في معرفة المعسيير وطرق

فحص الملفـات بواسطة الذكاء الاصطناعي ليس للمرشحين المستبعدين فقط ، وإنمسا أيضاً للغير.وقد رأى المجلس أنه وفقاً للنصوص يجوز للمرشحين بمجرد اتخاذ قرارات الرفض في مواجهته الحصول على المعلومات الخاصة بالمعايير وكيفية فحص طلبات ترشحهم. ومـع ذلك الحصول على هذه المعلومـات غير متـاح إلا للمرشـين، واعتبر

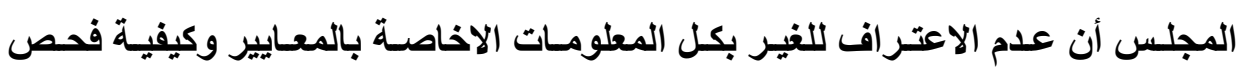
طلبات الترشح التي قبلت فعلًا من جانب المؤسسات المعنية ينطوي على اعتداء على الألى الحق الذي كفلته المـادة هـ 1 من إعلان حقوق الإنسـان والمـواطن (ץ)، وهو اعتـاء

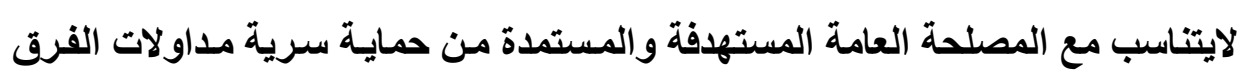
التريوية.ومن ثم لايجوز تفسير الأحكام المتنازع فيها، لايجوز تفسيرها على أنها تعفي كل مؤسسة من نشر تقرير يتضمن المعايير التي في ضوئها تم فحص المترشحين، ويوضح إلى أى مدى استخدمت معالجـات الخوارزميات للقيام بهذا الفحص وإلا تكون تلك الأحكام مخالفة لمبدأ الحصول على الوثائق الإدارية(ب).

(1)CC,12 juin 2018, n.765 DC, AJDA, 2018, p.1191 ;D. 2019, p.1248, chron. E.Debaets et N.Jacquinot.

(2) Selon cet article « La société a le droit de demander compte à tout agent public de son administration ».

(3)CC,3 avril 2020, n.834 QPC, D. IP /IT, n.9p.516, note T.Douville,

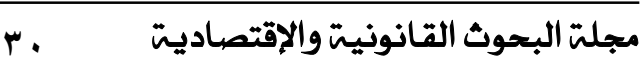


باختصار المبدأ هو شـفافية الخصائص الرئيسية للخوارزميـات أو المعالجـة

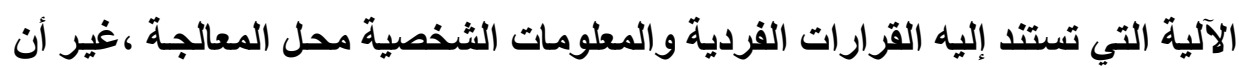
الثفافية في القانون الفرنسي ليست كاملة؛ لأنها لاتشمل بعض هذه الخصائص مثل رموز مصادر الخوارزميات( ).

ويعترف القانون حتى في الحسات التي يجوز فيها اتخـاذ قرارات معالجة آلياً بـالحق في طلب التدخل البشري، فيجوز لكل شخص كـان محلاً لهكذا قرار أن يطلب تدخل شخص بشري؛ بقصد الحصول على إعـادة فحص مركزه، وأن يعبر عن وجهة نظره، وويحصل على شرح للقرار المتخذ،، او ينازع فيه. عدم جواز الاستعانة بالذكاء الاصطناعي في بعض القرارات القردية: التوسع في اللجوء إلى اتخـاذ قرارات استناداً إلى الذكاء الاصطناعي يتوقف عند حدود ترسمها القوانين ، فلايجوز اللجوء غلى اتخـاذ قرارات آلية على هذا النحو

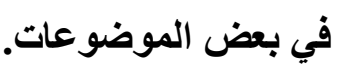

وعلى ذلك ينص قانون المعلومات والحرية في فرنسا على حظر اتخاذ أى قرار من القرارات التي يمكن أن تحدث آثثار آقانونيـة في مواجهة شخص مـا في حالة مـإذا كان أساس تلخلها الوحيد هو المعالجة الآلية للمعلومات المخصصة للتعريف بجاتب من شخصيته ( )، أو تقييم بعض جواتب من شخصيته( (). ولايجوز أيضاً اتخذ أى قرار

(1) «Codes sources d'algorithmes ».E.Mouriesse, L'opacité des algorithmes et transparence administrative, RFDA, 2019, p.45

(2) «Profilage»

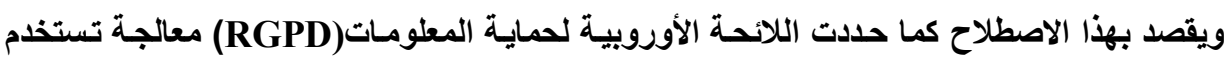

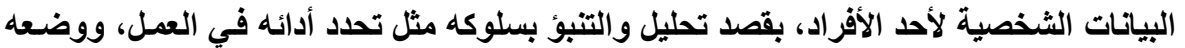
المالي، وحالته الصحية، وعادات لاته في الحياة. 


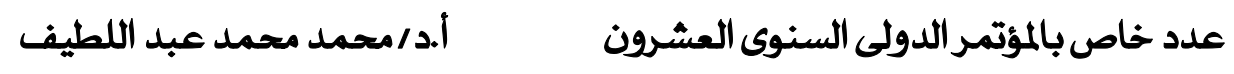

قضائي ينطوي على تقييم سلوك شخص ويكون أساسـه المعالجـة الآلية لمعلومـات ذات صفة شخصية من أجل تقييم بعض جوانب من شخصيته.

ومبأ الحظر في الحالة المتقدمة يقتصر على بعض أنواع من القرارات وهى

التـي تحـدث آثـاراً قانونيـة ، وكـلكك بعض عمليـات المعالجـة وهـى المعالجـة الآليـة للمعلومـات مـع تحديـا أو تقيـيم جوانب أو أجزاء مسن الثخصية، أو حتى الشخصية بأكملها.

ومن ثم يخرج عن نطاق هذا الحظر القرارات التي تتخذ في سياق إبرام أو

تنفيذ عقد، ويتم منح صاحب الشأن الفرصـة لتقديم ملاحظاته، أو القرارات التي تلبـي طلبات الشخص المعني (ץ).وكذلك القرارات التي تصدر بموافقة صريحة من الأشخاص المعنينين.

\section{الإطلب الثاني}

رقابة القضاء الإداري على القرارات الصادرة استتناداً للذكاء الاصطناعي إمكانية الطعن بالإلغاء في القرارات الصادرة استناداً إلى نظم الأكاء الاصطناعي: أصبح اصطلاح القرار المعالج إليكترونياً (ب) شنائعاً اليوم في القانون الفرنسي. ويقصد به كمـا تقول اللجنة الوطنيـة للمعلومـات والحريـات القرار المتخذ في مواجهة شـخص مـن خـلال خوارزميـات algorithmes أى معالجـة آليـة تطبـق على بياناتــه

(1) « Aspects de sa personnalité »

(2)J.Rochfeld, L'encadrement des décisions prises par algorithme, D. IP/IT, 2018, p.474

(3) « Décision automatisée » 
الثخصية مـن دون أى تـخل بشري في العملية.وهذا النوع مـن القرارات يمكن أن يتدخل في مجلات عديدة من أنشطة مثل الأنشطة المالية والضر ائب والتسويق، ويحدث آثاراً قانونية، أو تؤثر بطريقة مهمـة على للأشخاص أصحاب الشأن. مثال ذلك قرار رفض ائتمان يمكن أن يكون سنده الوحيداستخدام خوارزميات تطبق آلياً بعض المعايير على المركز المالي لطالب الائثمان دون أى تلخل بشري.

وهذا التعريف للقرار المعالج آلياً يحدث تحولاً كبيراً في حقيقة مفهوم القرار الإداري؛ لأنـه يعنـي أن القرار في حقيقته ليس تعبيراً عن إرادة الإدارة وحدها ، بـل تعبير عن نظام الذكاء الاصطناعي، حتى وإن ظل القرار من الناحية النظريـة منسوباً للإدرة التي تبنته بوصفه قراراها.

ويتولى القاضي الإداري في حدود اختصاصه رقابة المشروعية على القرارات

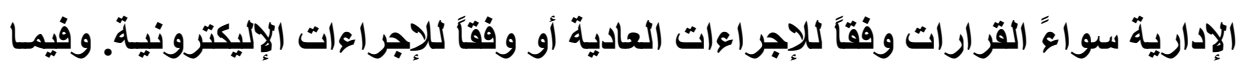

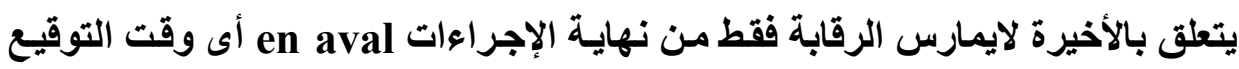
أو الإحالة ، ولكن أيضاً عند البدايـة en amont مـع الدعم أو المسـاعدة التي تقدمها الخوارزميات التي وتقوم بدور لايمكن إنكاره في بعض الدول الدول (1).

وعلى سبيل المثال يمكن إسناد دور للاككاء الاصطناعي في اتخذ القرارات ، فقد

يؤدي إلى اتخذ قرارات غير مشروعة، أو يرفض منح حقوق، أو يمنع الحصول على خدمـة، أو يقوم بتحليل شخصية المرشحين للوظائف على غرار مـا يحدث في مجـال المشروعات الخاصة، وقد ينتهي هذا التحليل إلى اختيارات تنظوي على التمييز (ץ).وقد

(1) Ph.Yolka, Le droit de l'immatériel public, AJDA, 2017, p.2047.

(2) J.-F.Kerleo, L'administration de produit, AJDA, 2020, p.2192 ; S.Sereno, Focus sur les discriminations par algorithme, Rev.de droit du travail, 2020,p.680. 
عدد خاص بالمؤتمر الدولى السنوى العشرون أ.د/محمد محمد عبد اللطيف

يكون التمييز عدياً من خلال وضع معيار تمييزي في برنسامج إليكتروني (1). واعتبرت

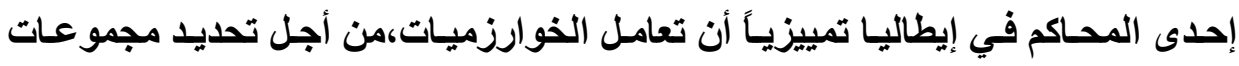

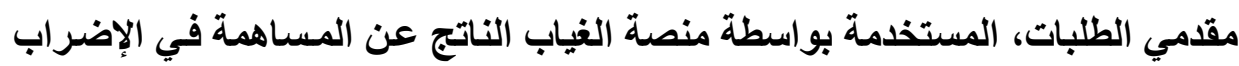

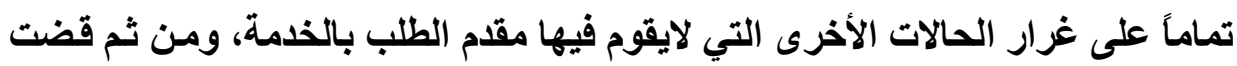

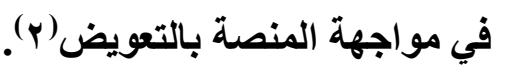

وفي إيطاليـا فيتم الاستعانة بـه مـن أجل تنفيـن الخطط الاستثنائية للتعيلين

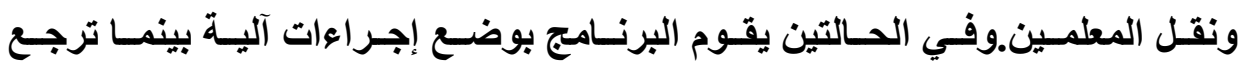

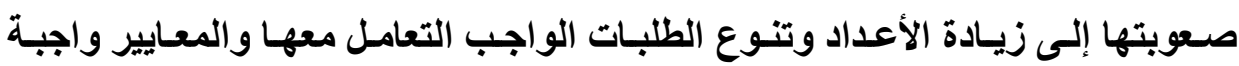

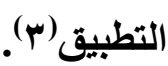

وقد كرس تقتين العلاقة بين الأفراد والإدارة في فرنسا إمكانية اتخذ قرار فردي

استناداً إلى معالجة حسابية. ونصت المادة L.311-3-1 من هذا التقنين على أنه:القرار

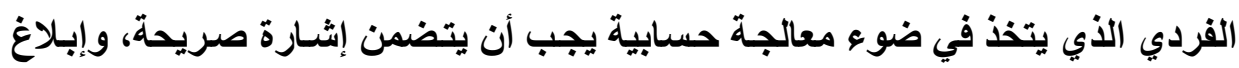

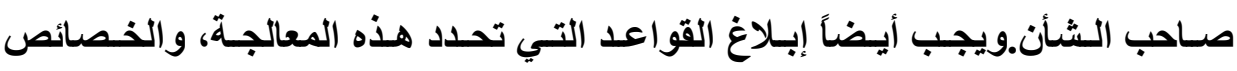
الرئيسية لتتفيذها من جانب الإدارة إلى صاحب الثئن منى طلب ذلك (ـ) .

(1) D.Gardes, Le droit à l'emploi face à l'intelligence artificielle, 2021,p.115.

(2) L.Ratti et M.Peyronnet, Controverse :Algorithme et risque de discrimination :quel contrôle du juge ?Rev,de droit du travail, 2021, p.81.

(3) G.Mancosu, Le contentieux des actes pris sur la base de d'algorithmes, un point de vue italien, Rev. générale du droit, 2019,n.49010

(4) Code des relations entre le public et l'administration, article L.311-2-1 cree par la loi n.2016-1321 du 7 octobre 2016. 


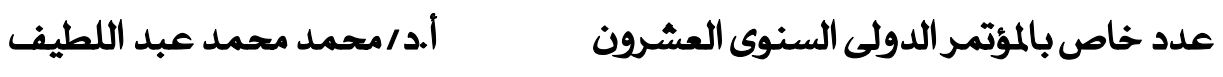

تحـولات فـي الرقابـة القضـائية علـى القـرارات الـصادرة اسـتنـاداً إلـى الــكاء الاصطناعي:

ولاجدال في إمكانية الطعن بالإلغاء في القرارات الصادرة استتاداً إلى مسـاعدة

من نظام الأكاء الاصطناعي أو المعالجة الحسابية ، كما يذكر تقنين العلاقة بين الأفراد والإدارة، مثلما يجوز الطعن بالإلغاء في أى قرارات أخرى ( ).

ومـع ذلـك كمـا يلاحظ بعض الكتـاب أن الأسـاليب التـي يعتمــ عليهـا القضاء

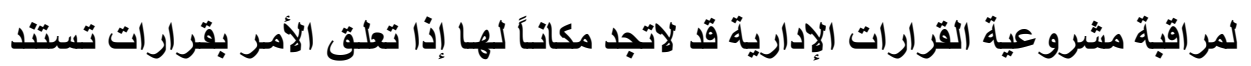

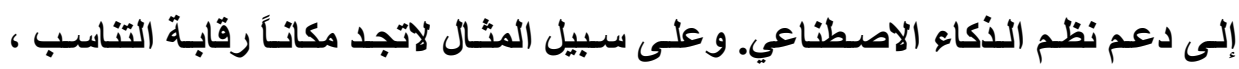
والخطأ البين في التقدير ؛لأن هذه الأساليب وغيرها تتفق مع الطريقة التقليدية في اتخاذ

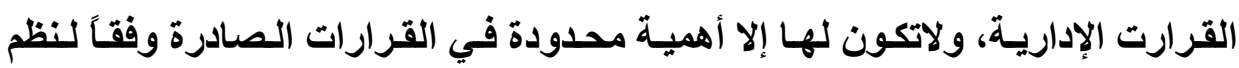
الأكاء الاصطناعي التي تعتمد على معايير محاسبية محض(ب) .ويرجع ذلك إلى أن هذه الأساليب تفترض ممارسة سلطة تقديرية مـن جانب الإدارة ، بينمسا اتخـاذ قرارات وفقة لنظم الأكاء الاصطناعي يتم بطريقة آلية متجردة من سلطة التقدير. ويضاف إلى ذلك أن نظم المساعدة في القرارتنطوى على تعميم تطبيق البيانات والمعلومـات التـي تتوافر لايسه، وهو مـايعني عدم تطبيق فحص كل حالة على حدة ،

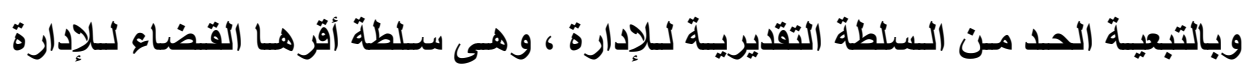
ممارستها وعدم التخلي عنها.

(1) J.-F.Kerleo, L'administration de produit, AJDA, 2020, p.2192 .

(2) J.B.-Auby, Le droit administrative face aux défis du numérique, AJDA, 2018, p.835 


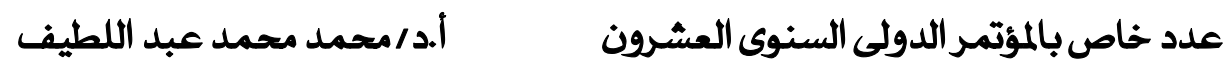

ونظراً لتوحيد المعسايير التـي تـتم في ضـوئهـا المعالجـة الآليـة للمعلومسات أو

البيانـات فيبدو صسعباً بـل مستحيلاً الادعـاء بوقوع القرار في عيب إسـاءة استعمال

السلطة.

ويثار التساؤل بطبيعة الحال عن مدى رقابـة القاضـي الإداري على المعلومـات

أو المعايير التي صدر استناداً إليها القرار الإداري.

بطبيعة الحل يمارس القاض الإداري رقابـة على هذه المعايير بمناسبة الطعن

بالإلغاء في القزار الصادر استناداً إليها؛ لأنها تشكل أساس القرار نفسه.

ولكن هل يجوز الطعن بالإلغاء في هذه المعلونـات والمعايير؟. لانرى مانعاً من

الطعن فيها بالإلغاء مباشرة في الميعاد مادامت ملزمة، قياساً على قبول دعوى الإلغـاء

في المنشورات الملزمة، بل إنها تشكل في حقيقة الأمر قرارات لائحية.

وبناءً على ذلك قضى مجلس الدولة بقبول الطعن بإلغاء توصية للجنة الوطنية

للمعلومـات والحريـة بشأن اعتبـار البيـان الخـاص بجنسية طالب القرض بوصفه أحـا

عناصر تقدير مخـاطر التحصيل، ورأى المجلس على عكس هذه التوصسي التي في

حقيقتهـا قراراً أن عنصر الجنسية منتج ولـيس تمييزيـاً فـي ضـوء عمليـة المعالجـة

الإليكترونية (1).

ويجوز أيضاً الافع بعدم مشروعية المعايير أو المعلومات التي يتم في ضوئها

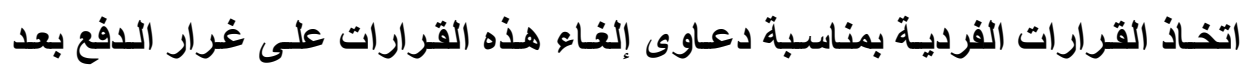

مشروعية القرارات اللائحية بصفة عامة.

(1) CE, sec., 30 oct.2001, n.204909 


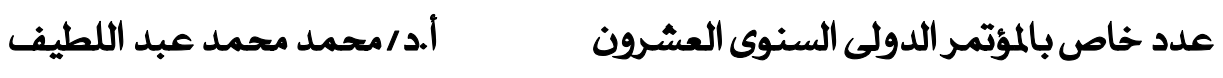

رقابة القضاء الإداري في إيطاليا على القرار اللائحي بفرض استخدام نظم الذكاء الاصطناعي في إصدار القرارات الفردية:

وفي إيطالياً يراقب القاضي الإداري مشروعية القرار اللائحي بفرض استخدام

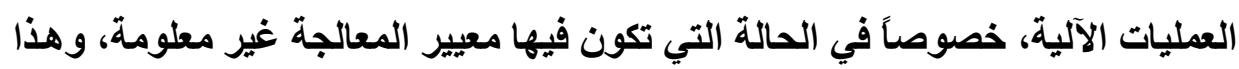

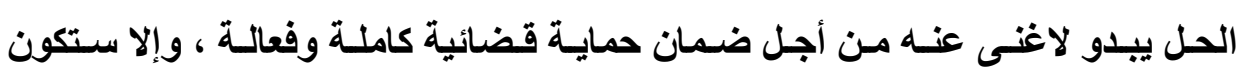

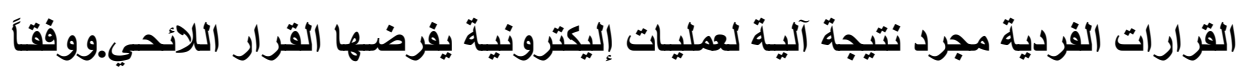
للقضاء في إيطاليا إذا مـا طبقت معايير موضوعية دون أى هـامش تقدير من السلطة

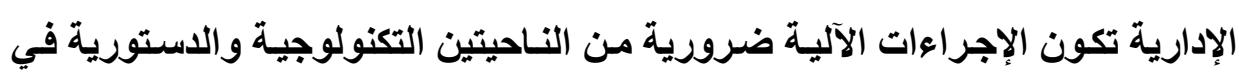
ضوء المادة V9 من الاستور. والرنامج الإليكتروني في نظر القضاة يجسد الإجراءات الإدئ

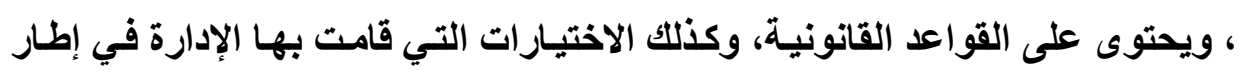
حريتها في التقدير. وقد حرص القضاء الإيطالي على إبراز النتيجتين الآتيتين: أمسا النتيجة الأولى فهى أنه يقع على الإدارة المسئولة عن الإجراعات أن توازن من البداية أى قبل تنفيذ البرنامج بين جميع المصالح المعنية، ممـا يفرض أيضاً إدخـال

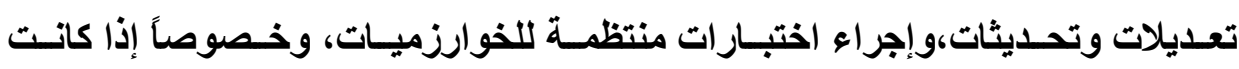
الأخيرة هى خوارزميات تعلم آلي أو تعلم عميق. وأما النتيجة الثانية فهى أن قابلية الخوارزميات للتقاضي تفترض أنها مفهومة من جانب القضاة والمواطنين ، وهذا يفرض أن تكون جميع جوانبها مهروفة مثل مؤلفيها، وإجراعات إعدادها، ونظام القرارات( ).

(1) G.Mancosu, Le contentieux des actes pris sur la base de d'algorithmes, un point de vue italien, Rev. générale du droit, 2019,n.49010. 


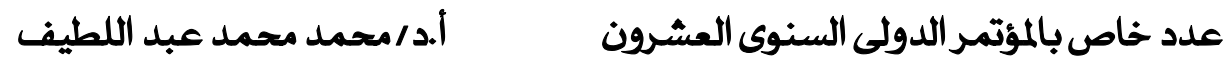

\section{الإطلب الثالث}

\section{المسئولية عن الذكاء الاصطناعي في القانون الإداري}

تلجأ السلطات الإداريـة إلى استخدام الذكاء الاصطناعي سواءً بمناسبة إتخـاذ

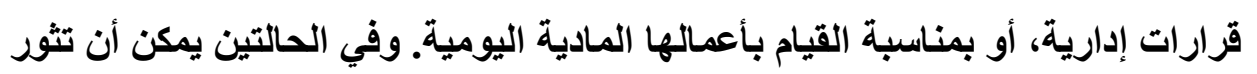

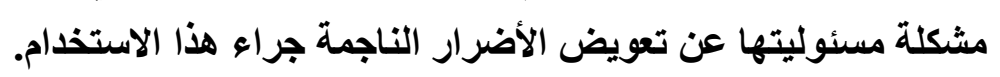

المسئولية الإدارية عن القرارات الإدارية المعالجة آلياً:

في الحالات التي تتخذ الإدارة فيها قراراً معالجًا آليا تنعقد مسئوليتها إذا كـان

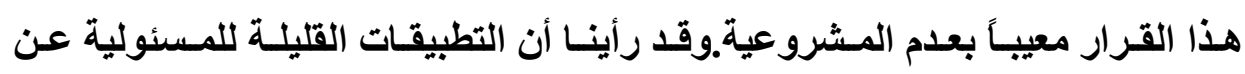

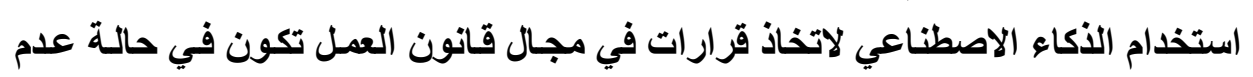

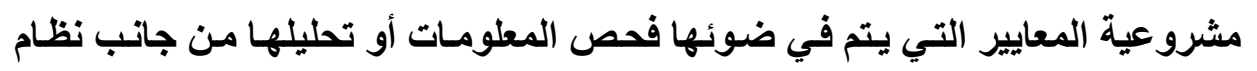

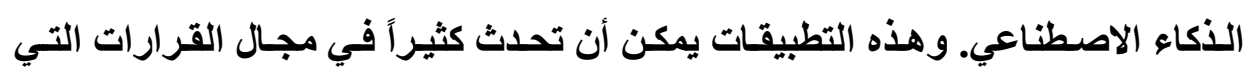
تصدر عن السلطات الإدارية.

ويمكن أيضاً طلب التعويض عن اتخـاذ قرارات معالجة آلياً في الحسالات غير

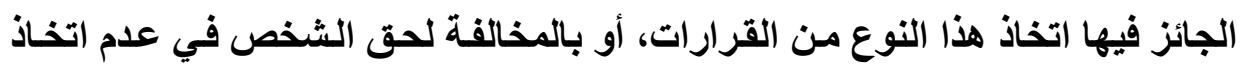

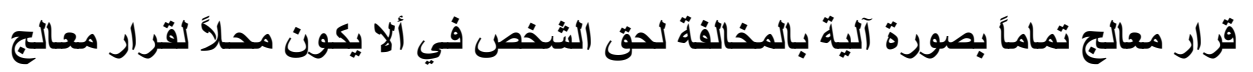

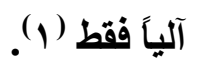

ونظراً لأن المسئولية عن القرارات الإداريـة هى في الأصل قائمسة على الخطأ

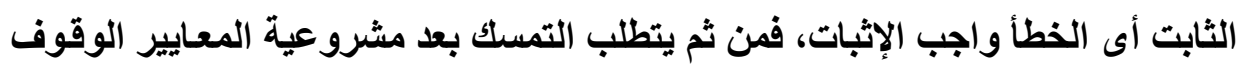

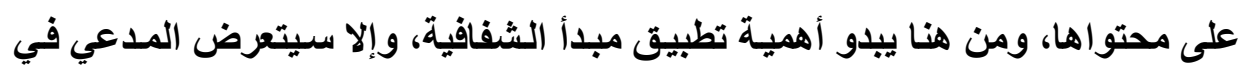
دعوى المسئولية لمشكلة في الإثبات. ومع ذلك يقع على القاضي الإداري التذخل بـإلزام

(1) J.Groffe-Charrier, La loi est-elle dictée par le code ? D.IP/IT, 2020, p. 602. 
الإدارة بإبراز هذه المعايير، تطبيقًا للاور الذي يقوم به في الإجراءات القضائية الإدارية وهى إجراءات توصف دائماً بأنها موجهة.

ويقدم القضاء في إيطاليا تطبيقـا مهمـاً للمسئولية عن القرارات المعالجة آليا.

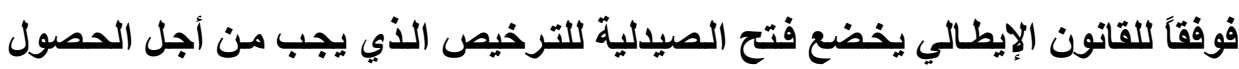
عليه تقديم طلب في منصة إليكترونية تابعة لوزارة الصحة.ويجب أن يقدم الطلب لإقليم

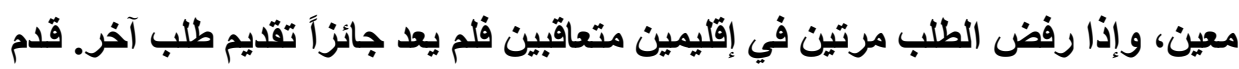

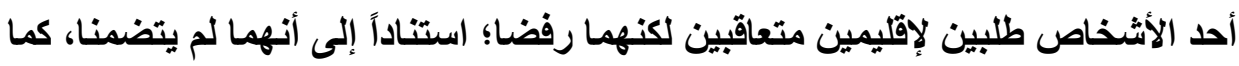

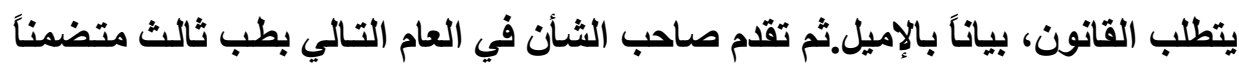

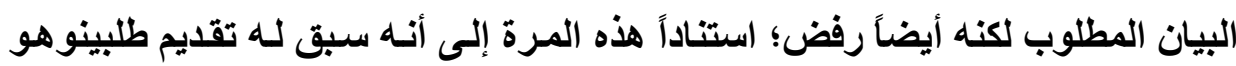

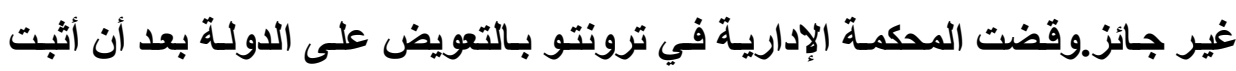

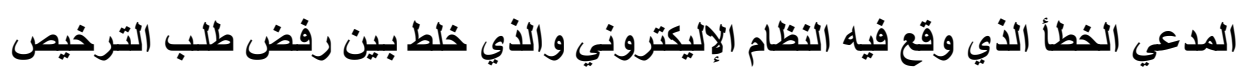
لسبب شكلي مع رفض الطلب لسبب موضوعي (1). ويجوز التعويض أيضاً عن القرار اللائحي المنظم لاستخدام الأكاء الاصطناعي.

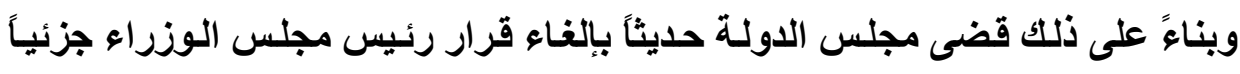

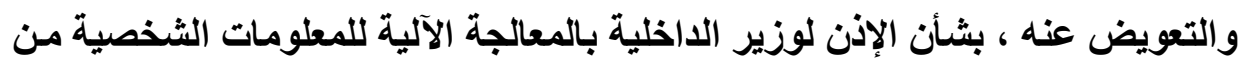

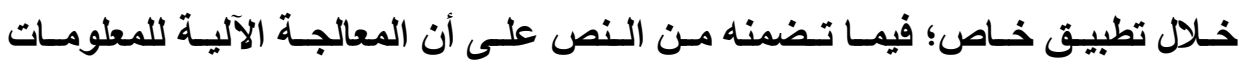

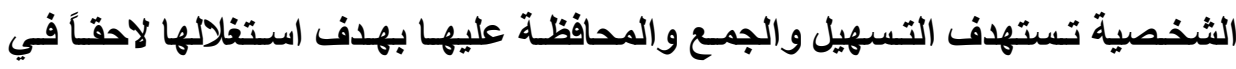
معالجات أخرى للمعلومات، ولاسيما من خلال نظام المعلومـات المسبقة؛ لأن القرار لـ لـ

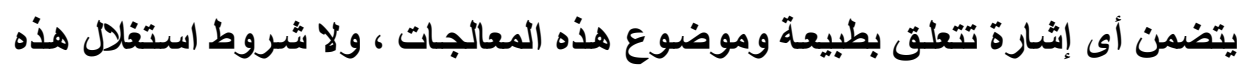

(1) Cite in J.-B.Auby,Le droit administrative face aux défis du numérique, AJDA, 2018, p.835. 
المعلومات في تلك المعالجات، ومن ثم لاتتو افر في هذه الغاية المتطلبات التي يشترطها

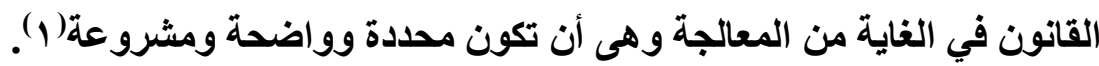

وعدم المشروعية الذي يمكن أن يهـد القرار المعالج آلياً يشكل دائمساً خطاً

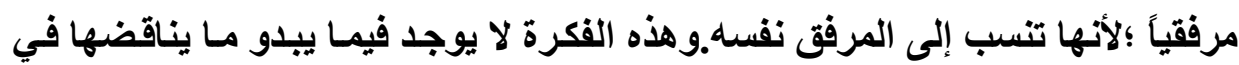

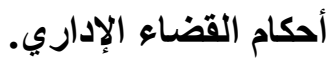

المسئولية الإدارية عن الأعمال المادية تنفيذاً لنظام الأكاء الاصطناعي:

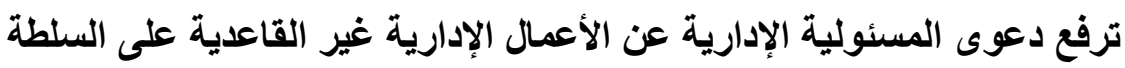
العامة التي تستخدم نظام الذكاء الاصطناعي وليس الثخص الإدية الأي أنتجه(ץ). ويثار التساؤل عن أسساس المسئولية الإداريـة عن الأضـرار الناجمـة جراء

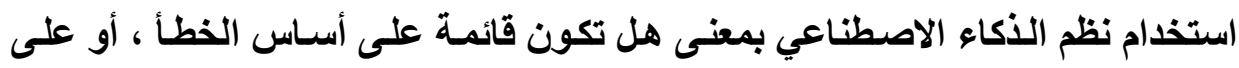
الخطأ المفترض، أو من دون خطأ ؟ الاصناع 1 - استبعاد المسئولية على أساس الخطأ الثابت:

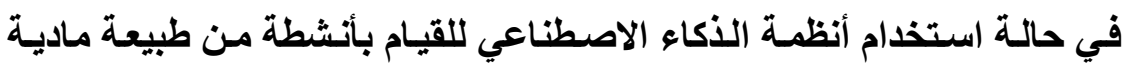
امثل الأعمال الطبية أو النقل سيجد المضرور عقبة كبيرة في تحديد الخطأ، وتحديد

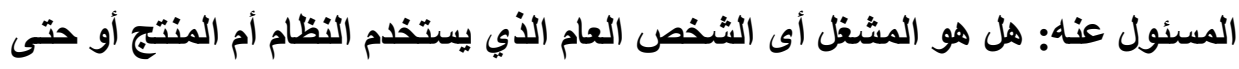

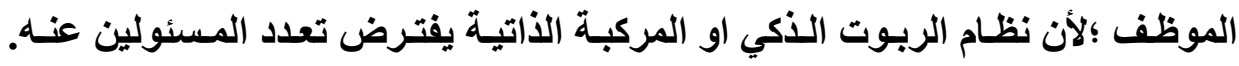

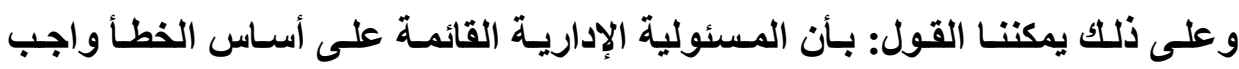

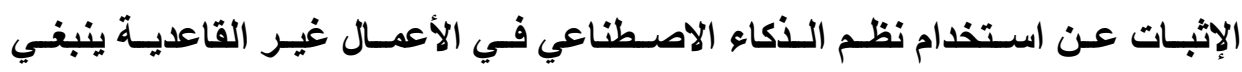

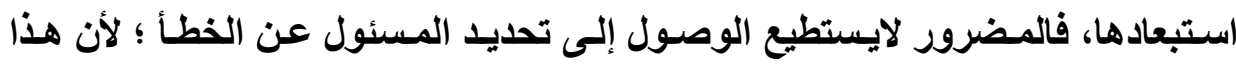
التحديد يبدو مسألة فنية ودقيقة لن يتمكن في الغالب من إثباتها.

(1) CE, 10 -ème et 9 -ème chambres réunies, 13 av.2021, n. 439360.

(2) J.-F.Kerlio, L'administration de produit, AJDA, 2020, p.2192. . 


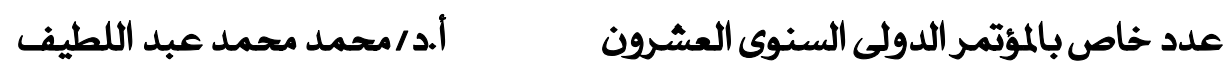

ومسن المعلـوم أن القـانون يستبعد المسئولية على أسـاس الخطـأ الثابـت في

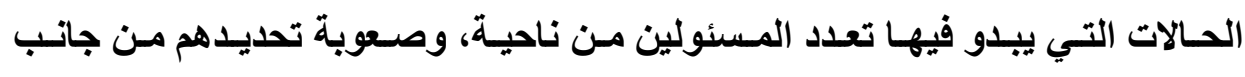

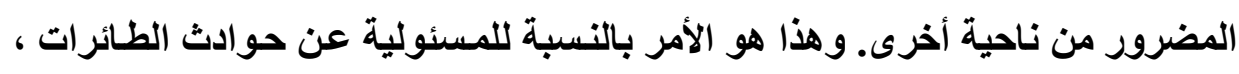

$$
\text { والمسئولية عن الأضرار النووية. }
$$

ץ- مدى تطبيق نظسام المسئولية على أسساس الخطأ المفترض والمسئولية دون خطأ:

قد يبدو ممكناً اللجوء إلى المسئولية القائمسة على أسساس الخطأ المفترض أو قرينـة الخطـأ ، وهو منطق نظسام المسئوالية عن فعل الشئ ، وخصوصاً في مجسال

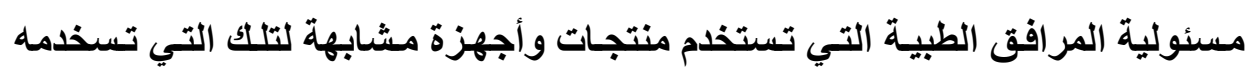
المستفيات الخاصة.ومع ذلك يبدو فقه القانون العام متحفظاً على تطبيق هذا النوع من

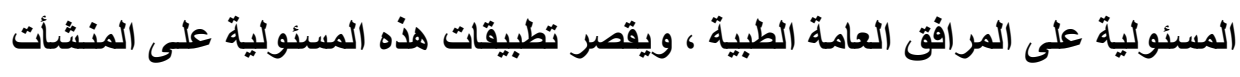
والأشغال العامة والأسلحة الخطرة، وخصوصاً لعدم تحديد مفهوم معنى الثئ. ومع ذلك فقد تحقق مؤخراً تطبيق قواعد القانون المدني على مسئولية المرافث

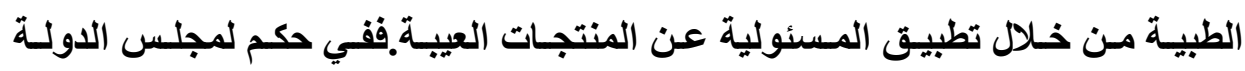

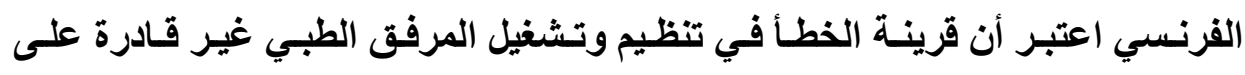

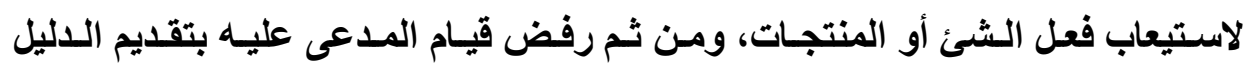
العكسي الذي يستهدف قلب قرينة الخطأ. ويقرر مجلس الدولة أن المرفق العام العام الطبي

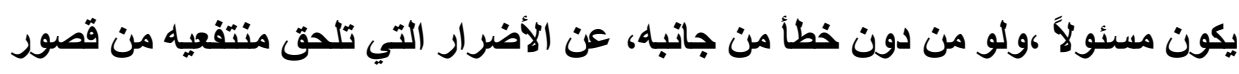

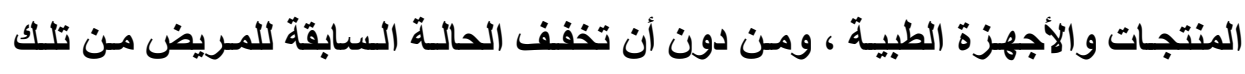

(1)CE, 9 juillet 2003, n.220437, Assistance publique-Hôpitaux de Paris AJDA,2003, p.1964, note M. Deguergue. 
ويستند هذا القضاء إلى مبدأ مهم يخضع له المرفق الطبي وهو الالتزام بسلامة

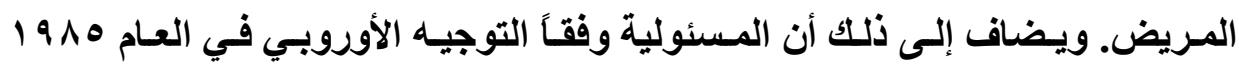
وقانون 19 19 بشأن المسئولية عن المنتجات المعيبة هى مسئولية موضوعية ، بل إن إن الن

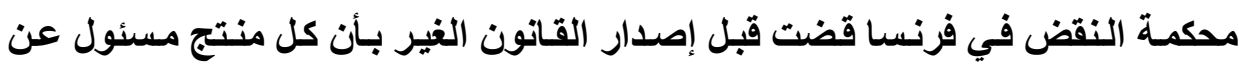

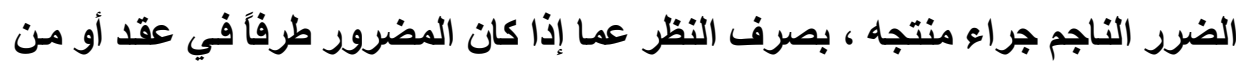

وأكد المجلس هذا القضاء في حكم لاحق( ).

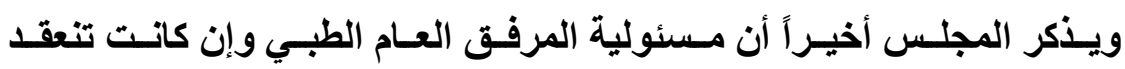

دون خطأ،إلا أن ذلك لايخل بحقه في الرجوع بالدعاوى التي يمكنه أن يمارسـها على التى المنتج.

وهذا القضاء يصلح للتطبيق بطبيعة الحال على استخدام المرافق العامة الطبية

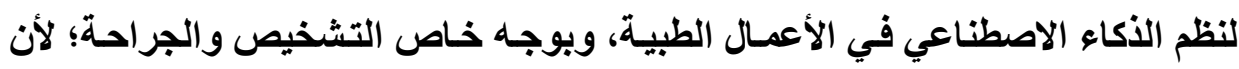
أساس المسئولية واحد ألا وهو المسئولية عن المنتجات المعيبة.

ومن ثم يمكن أن نخلص إلى نتيجة مؤداهـا أن المسئولية عن استخدام نظم

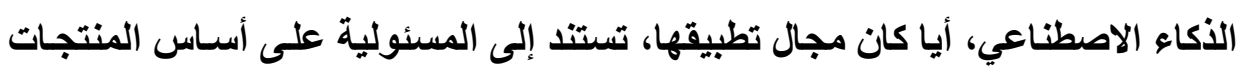

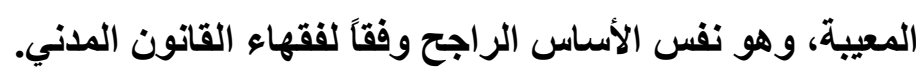
وهذا التحليـل يمكن تطبيقهـ أيضاً أمسام القضاء الإداري في مصر؛ نظراً لأن

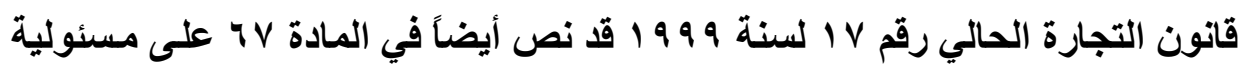
المنتج عن المنتجات المعيبة، وجعل المشرع هذه المسئولية موضوعية.

(1)CE, 12 mars 2012, n.327449, Centre hospitalier universitaire de Besançon, AJDA, 2012, p.575. 


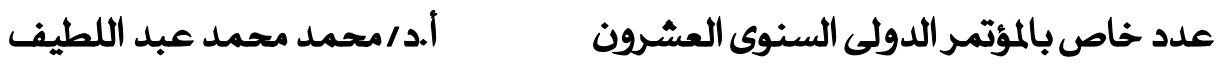

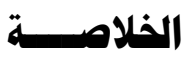

أحدث الأكاء الاصطناعي تطورات بالغة الأهمية في مختلف المجالات. وهذه

التطورات تستدعي تدخلاً من جاتب القانون لمواجهتها، وخصوصاً فيمـا يتعلق بإصدار القرارات وفقاً لنظم الأكاء الاصطناعي التي أصبحت تتخذ بطريقة آلية محضة. وهذا التدخل التشريعي ضروري للحد من اتساع هذه القرارات ؛ لأنها يمكن أن تشكل تهديداً بعض حقوقه الأساسية مثل الحق في الحياة الخاصة.

وفيما يتعلق تحديداً بالمسئولية المدنية عن استخدام الذكاء الاصطناعي وجدنا أن غالبية الفقهـ لا ترى الآن مبرراً لتـخل المشرع ، وأن أسـاس هذه المسئولية هو المسئولية عن المنتجات المعيبة، واحتياطياً المسئولية عن فعل الأثياء. وفي القانون المسصري يتـوافر كـل مـن نـوعي المسئولية أى المسئولية عـن المنتجــات المعيبـة والمسئولية عن فعل الشئ.

وفيما يتعلق بالمسئولية الإدارية فقد تطور القضاء الإداري إلى درجـة اعتبار

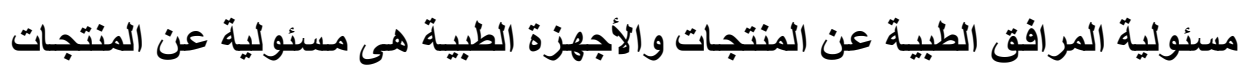
المبيعة. ومن هنا يمكن دون أى صعوبة اعتبار هذه المسئولية الأخيرة قابلة للتطبيق أمام القاضي الإداري فيما يتعلق بالمسئولية عن استخدام تقنيات الأكاء الاصطناعي في مجالات الطبي والانتقال على سبيل المثال. واعتقد أن تطبيق هذه الحلول لاتعترضسه أى لى صـوبات في القـانون المـصري، وخصوصاً بعدما طبق القاضسي افـاري في مجـال المسئولية الطبية مبدأ المسئولية دون خطأ. 


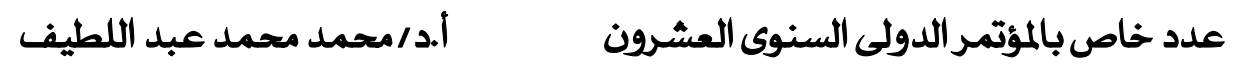

\section{لالمهوعلف}

الأبحاث المتخصصة باللغة العربية:

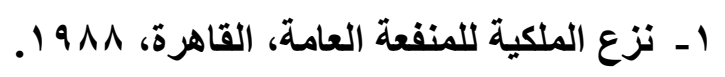

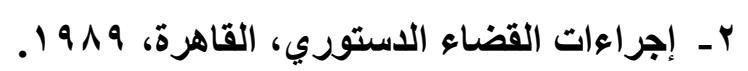

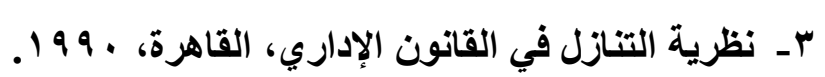

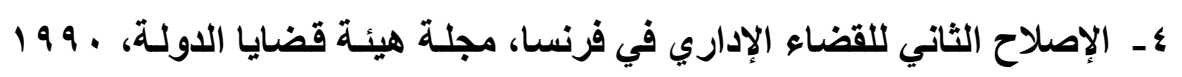

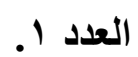

هـ التنظيم القـانوني لتمويـل الحيـاة السياسية فـى فرنسسا، دراسـة خاصـة عـن

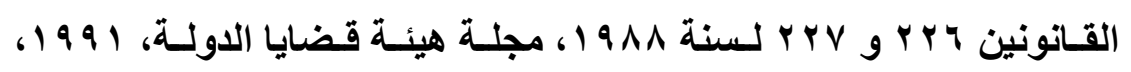

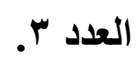

7ـ دستورية حظر البـــاء على الأراضـي الزراعيـة، تعليق على حكم المحكسة

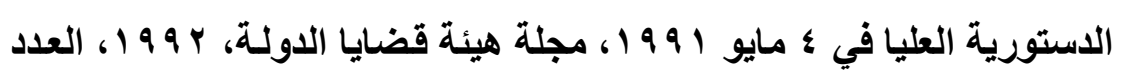

\section{r}

V- التصحيح التثريعي، القاهرة، اه9 9 ا ـ (الكتاب الحائز جائزة جامعة المنصورة

$$
\text { (التشجيعية). }
$$

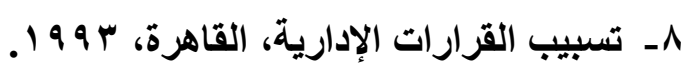

9- القيمة الاستورية لقرينة البراعة، تعليق على حكم المحكمة الاستورية العليا

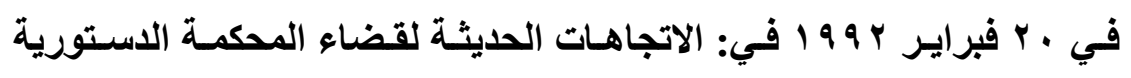

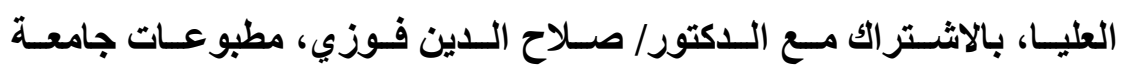

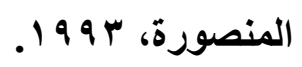

• 1 ـ قضية سوق روض الفرج، دراسة تحليلية نقدية لحكم المحكمة الإداريـة العليا

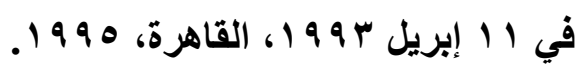




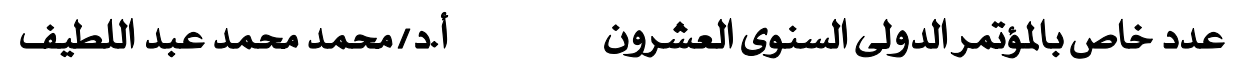

1 - ـ حريـة الإذاعة المسموعة والمرئية، بحث مقدم إلى مؤتمر الإعلام والقانون

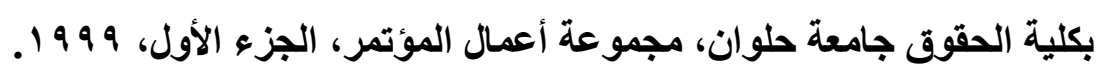

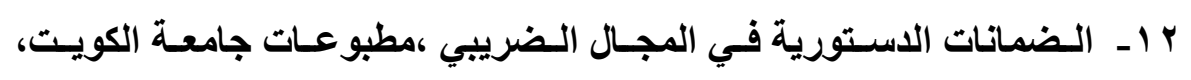

.1999

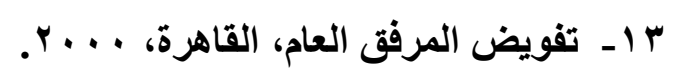

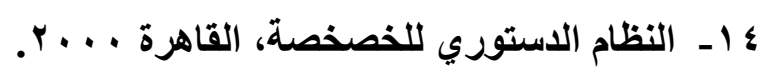

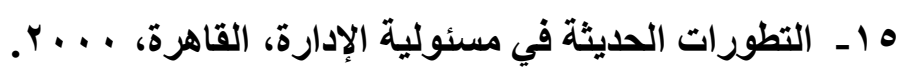

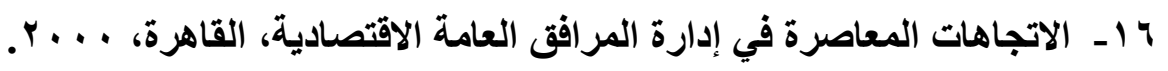

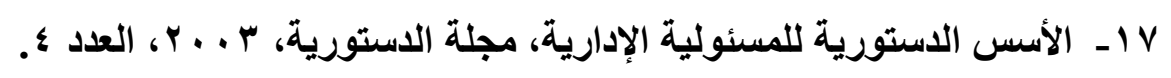

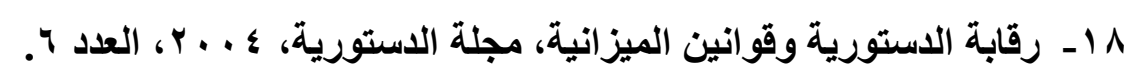

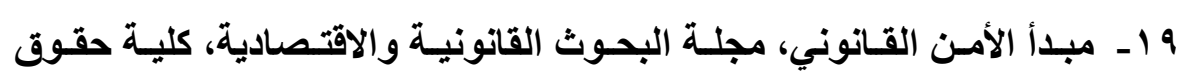

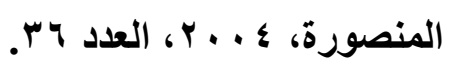

• . ـ أحكام تأمين الكوارث الطبيعية في القانون الإداري، مجلة الحقوق للبحوث

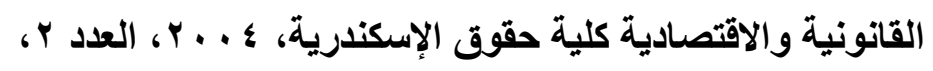

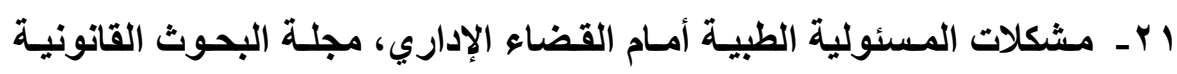

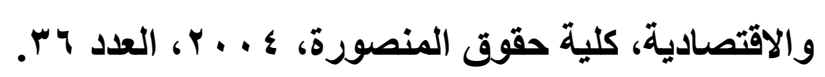

r r ـ الأحكام الخاصة بالأضرار القابلة للتعويض في القانون الإداري، مجلة كلية

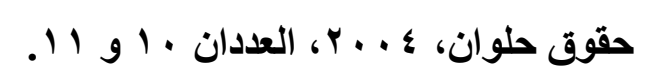

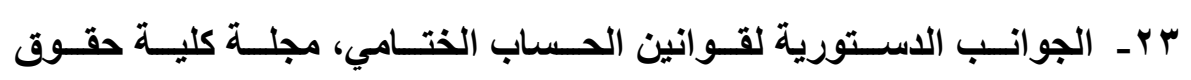

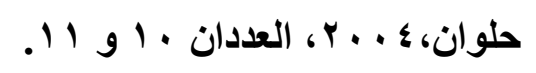

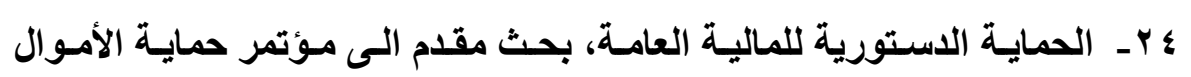

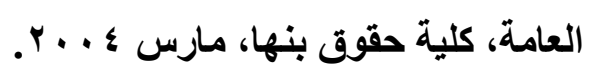




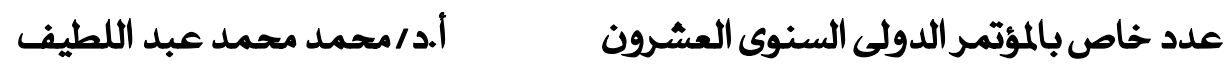

ه r - الأشخاص العامة وقانون المنافسة، بحث مقدم إلى مؤتمر "تنظيم المنافسة

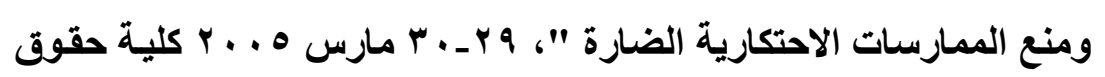

$$
\text { المنصورة. }
$$

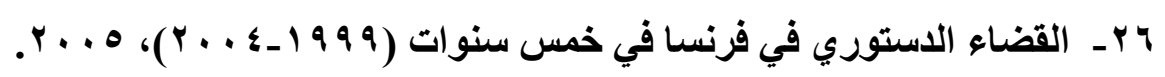

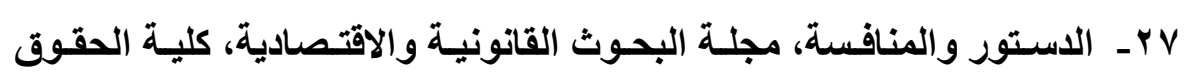

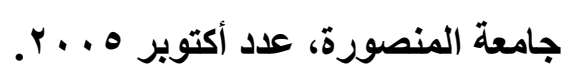

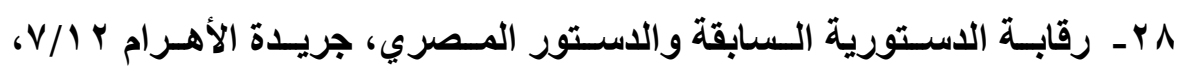

$$
r \cdot 0 / V / 19
$$

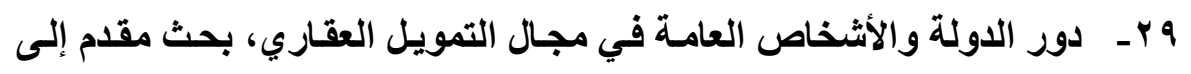

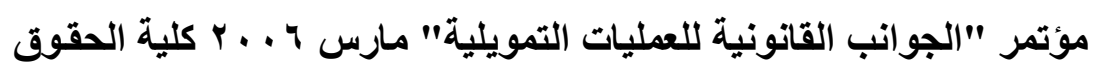

$$
\text { جامعة الكويت. }
$$

• بــ المبادئ الاستورية والإداريـة في مجـال الهندسـة الوراثية، بحث مقدم إلى

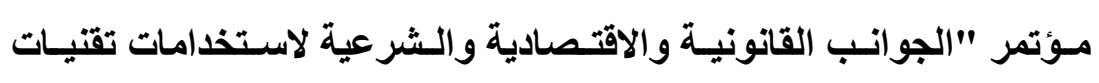

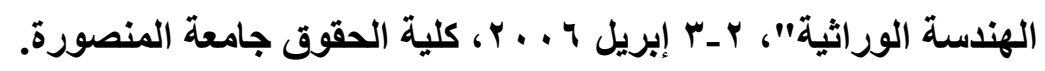

ابـ التعديلات الاستورية وقوانين الميزانية، بحث مقدم إلى مؤتمر " الإصـلاح

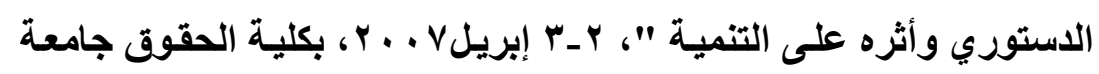

$$
\text { المنصورة. }
$$

r r- التعديلات الدستورية والبيئة، بحث مقدم إلى مؤتمر " الإصدلاح الاستوري

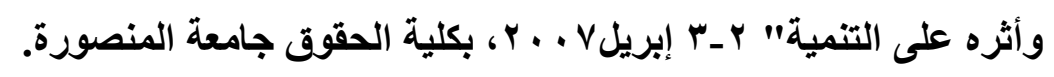

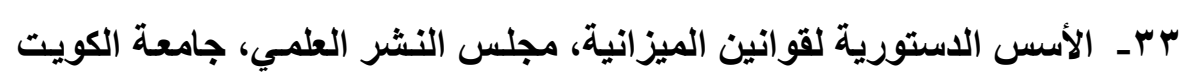

$$
r \cdot v
$$

ـ بـ الاستور الكويتي وخصخصة المرافق العامة وعقود المشاركة وعقود البنـاء 


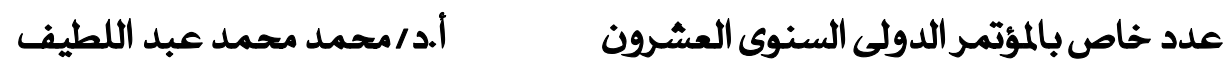

والتشغيل ونقل الملكيـة، بحث مقدم إلى مؤتمر "الجوانب القانونيـة لأمـلاك

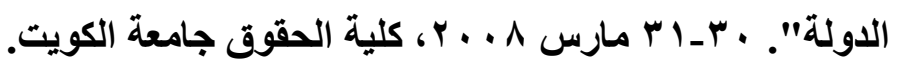

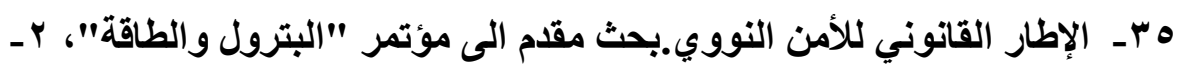

r ابريل ^ ^ . . r، كلية الحقوق جامعة المنصورة.

צr-- سلطة تنظيم الأسواق المالية. الإطار الاستوري والتظيم التشريعي ،مجلة

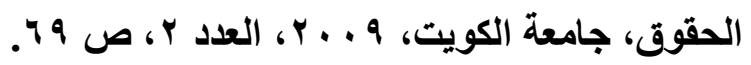

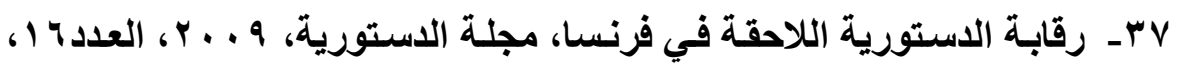

$$
\text { ص }
$$

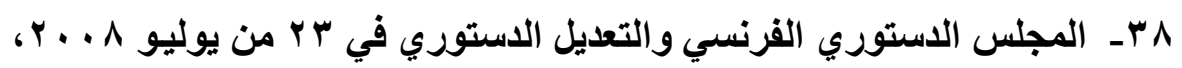

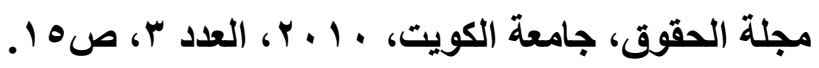

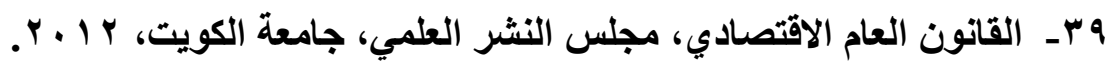

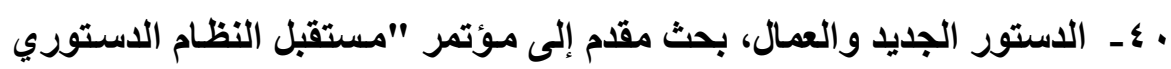

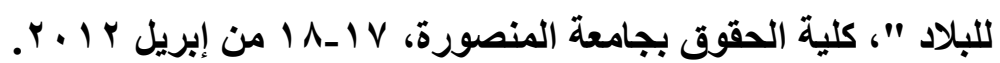

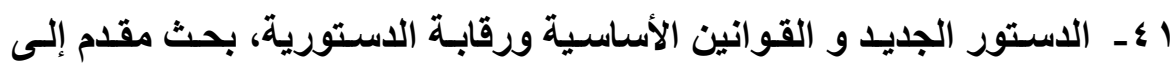

مؤتمر "مستقبل النظام الاستوري للبلاد"، كلية الحقوق بجامعة المنصورة،

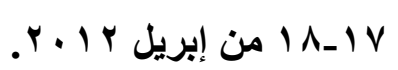

ץ ـــ الاستور الجديا و الجيش، بحث مقدم إلى مؤتمر "مستقبل النظام الدستوري

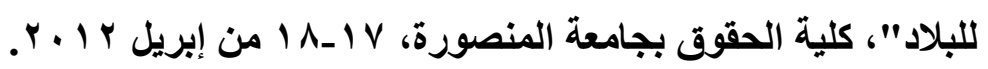

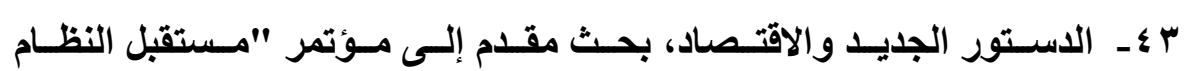

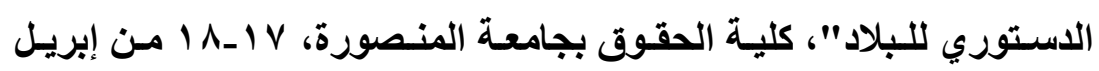

$$
\text { . } r \text {. Ir }
$$

؟ ء ـ الطاقة النووية والقانون، مجلة عالم الفكر ،الكويث، المجلد اء؟، العدد الثالث 


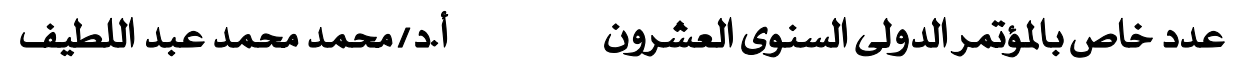

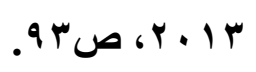

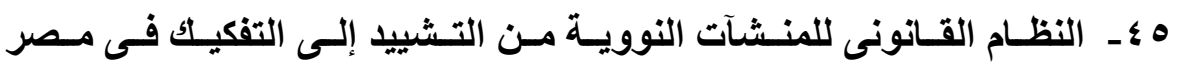
والإمارات، بحث مقدم إلى مؤتمر "الطاقة بين القـانون والاقتصاد"، كلية

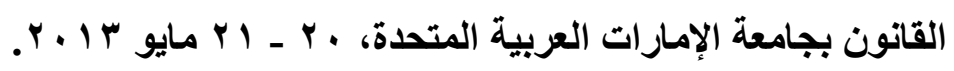

צ ؛ـ القانون الإداري للأموال، الكتاب الأول، الأملاك العامة ونزع الملكية للمنفعة

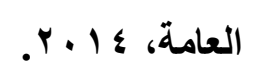

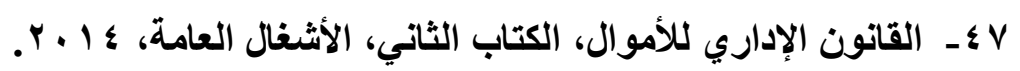

^ ـ ـ الهيئة العربية للطاقة الذرية والإيراتوم، بحث مقدم إلى مؤتمر مصر والعـالم

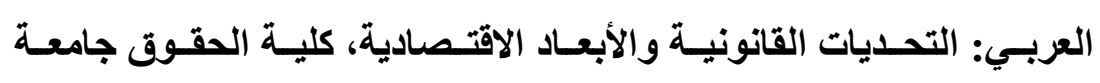

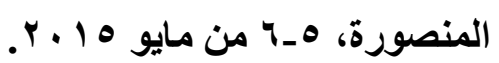

$$
\begin{aligned}
& \text { 9 §ـ القانون النووي، القاهرة } 17 \text { ـ ب. }
\end{aligned}
$$

•ــ المشروع النووي المصري ،الإطار القانوني والبنيان المؤسسي، بحث مقدم إلى مؤتمر الأبعاد القانونية والاقتصادية للمشروعات القومية، كلية الحقوق

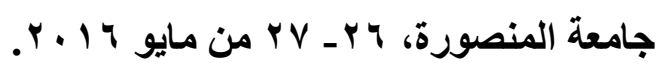

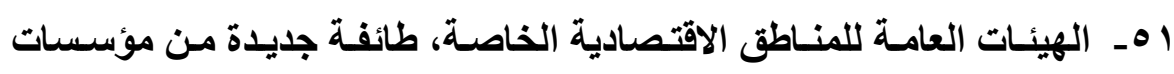

التــلـل الاقتصـادي في مـصر، بحـث مقـدم إلـى مـؤتمر الأبعـاد القانونيـة

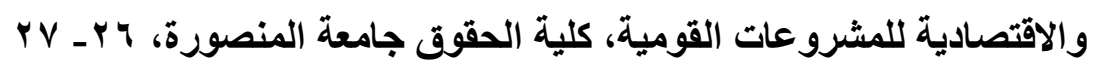

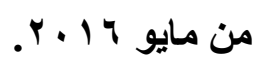

r ـ المرافق والمشروعات العامة الثقافيـة القوميـة، بحث مقدم إلى مؤتمر الأبعاد

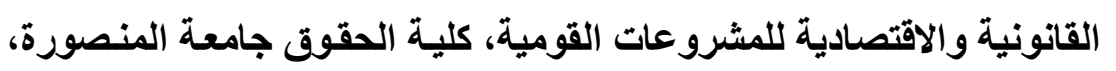

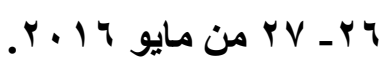

بهـ ـ تعظيم القيمة الاقتصادية لأموال المشروعات العامة القومية، بحث مقدم إلى هـ 


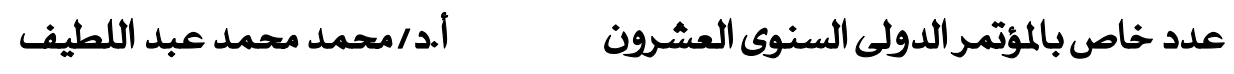

مـؤتمر الأبعـاد القانونيـة والاقتصادية للمشروعات القوميـة، كليـة الحقوق

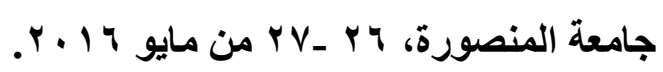

؟ ــ التظيم القانوني للهجرة الشرعية، بحث مقدم إلى مؤتمر الأبعاد القانونية للهجرة غير الثرعية وآثارها على التنمية، كلية الحقوق بجامعة المنصورة،

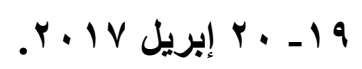

هــ ضمانات المهاجرين غير الثرعيين في أوضاع الانتظار والاحتجـاز والإبعاد، بحث مقدم إلى مؤتمر الأبعاد القانونيـة للهجرة غير الشرعية وأثارهـا على الثى

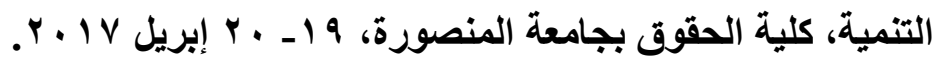
צهـ - حقوق المهاجرين غير الشرعيين، بحث مقدم إلى مؤتمر الأبعاد القانونية للهجرة غير الثرعية وآثار ها على التنمية، كلية الحقوق بجامعة المنصورة،

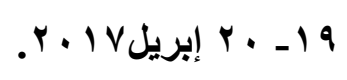

Vهـ - جرائم الهجرة غير الثرعية بين الإطار الدستوري والتوجيه الأوروبي، بحث مقدم إلى مؤتمر الأبعاد القانونية للهجرة غير الشرعية، كلية الحقوق بجامعة لإنة

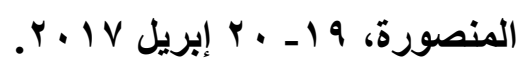

^هـ جزاعات سلطة تنظيم الأسواق المالية وضمانات المحاكمة المنصفة ، القاهرة

$$
\text { . r. I1 ، }
$$

9هـ القانون الناعم قانون جديد للسلوك الاجتمـاعي ، مجلة عـالم الفكر،المجلس

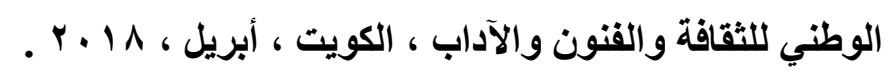

• 7ـ موسـوعة القـانون النـووي ، جـزعان ، دار القكر والقـانون ؛ المنـصورة ،

$$
r .19
$$

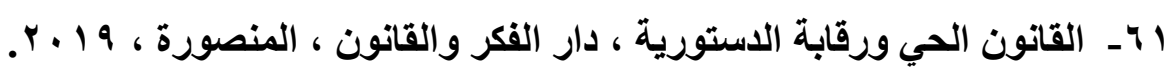
r ب - الاستثمار والنظام العام الاقتصادي ، بحث مقدم إلمؤتمر العربي للاستثمار 


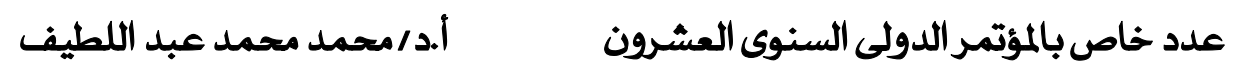

والتنميـة، نحـو بيئـة تششريعية جاذبـة للاسـثنمـار ، كليـة الحقـوق بجامعـة

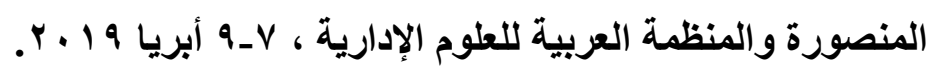

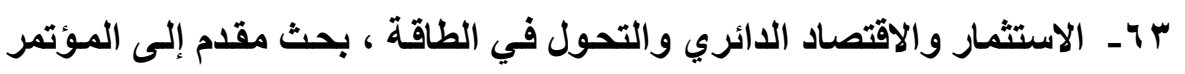

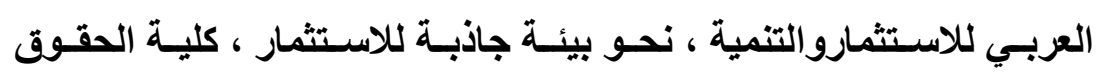

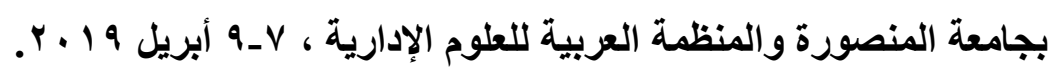

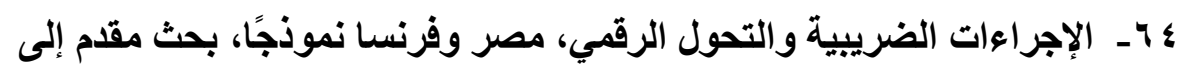

الندوة الدولية الإليكترونية بعنوان نظام الدفع والجباية المالية في ظل البيئة الإليكترونيـة التي نظمتهـا كلية القـانون بجامعة القلوجـة بـالعراق، 10 مـن

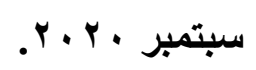

ه 7- الوظيفـة الاجتماعيـة للشركات، المجلـة الدوليـة للفقهـه والقضاء والتشريع،

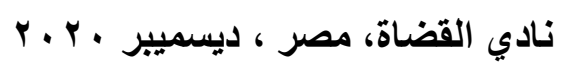

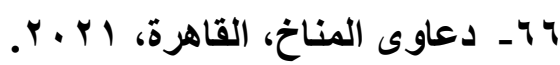

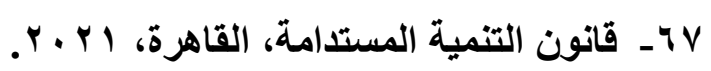

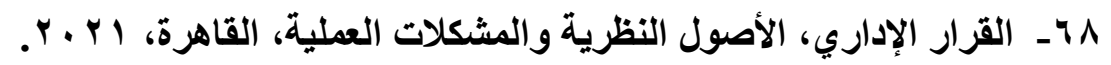
9 7 - الإطار القانوني للاقتصاد التعاوني عبر المنصات الإليكترونية، بحث مقدم

إلى مؤتمر الجوانب القانونية والاقتصادية للذكاء الاصطناعي وتكنولوجيا

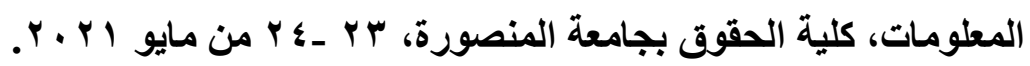

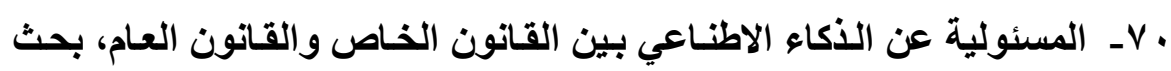

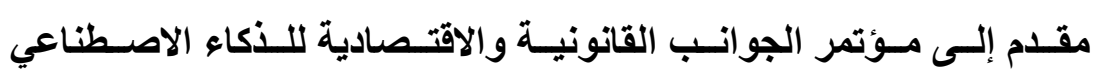

وتكنولوجيا المعلومات، كلية الحقوق بجامعة المنصورة، بr _ _ ب من مـايو 
عدد خاص بالمؤتمر الدولى السنوى العشرون أ.د/محمد محمد عبد اللطيف

\section{المراجع المتخصصة باللغة الفرنسية:}

'Le contentieux des élections parlementaires, thèse $-v$ ' Université de Dijon, 1983 (Ouvrage récompensé par le Centre français de Droit comparé à Paris)

L'expropriation au pays des pyramides, Etudes $-V Y$ foncières, Paris, décembre 1988

La protection constitutionnelle des droits économiques $-V r$ et sociaux en Egypte et en France, Arab Law quarterly,

$$
\text { v. 19, 2004, P.225 }
$$

La constitutionnalité de la législation sur la justice $-V$ \& constitutionnelle au Koweït, Revue française de Droit constitutionnel, 2007, n. 69

La régulation du marché du crédit foncier en Egypte, - $v^{\circ}$ Revue internationale de Droit comparé, 2008, n.1

$$
\text { المراجــع العــامة: }
$$

7.V. - الحريـات العامـة، وحدة التـأليف والترجمـة والنشر بكليـة حقوق الكويت،

$$
.1990
$$

النظم السياسية، وحدة التـأليف والترجمـة والنشر بكليـة حقوق الكويـ، -VV

$$
199 \mathrm{~V}
$$

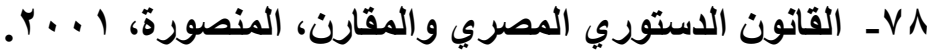

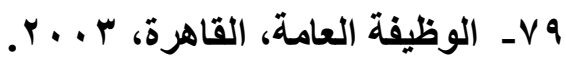




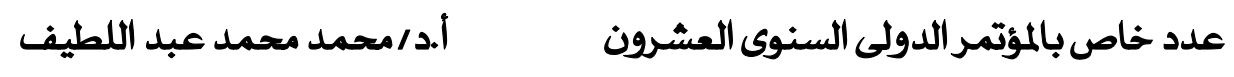

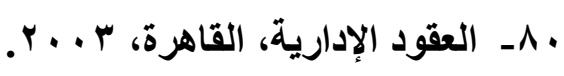

ا 1ــ قـانون القـضاء الإداري، الكتــاب الأول، نظــام القـــاء الإداري، القــاهرة،

$$
\text { r. . } 1
$$

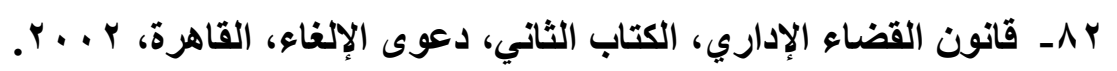

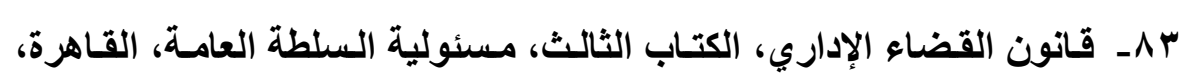
. $r$.

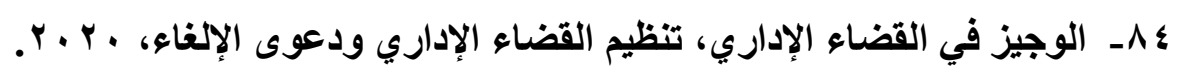

